\title{
Expedition 336 summary ${ }^{1}$
}

\author{
Expedition 336 Scientists $^{2}$
}

\section{Chapter contents}

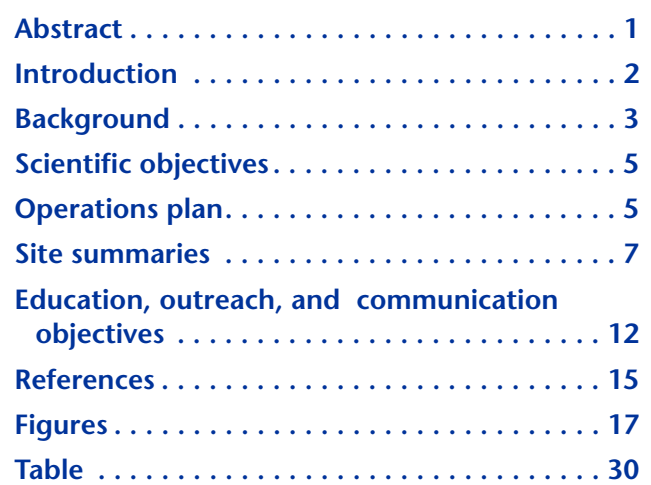

${ }^{1}$ Expedition 336 Scientists, 2012. Expedition 336 summary. In Edwards, K.J., Bach, W., Klaus, A., and the Expedition 336 Scientists, Proc. IODP, 336: Tokyo (Integrated Ocean Drilling Program Management International, Inc.). doi:10.2204/iodp.proc.336.101.2012

'Expedition 336 Scientists' addresses.

\section{Abstract}

Integrated Ocean Drilling Program (IODP) Expedition 336 successfully initiated subseafloor observatory science at a young mid-ocean-ridge flank setting. All of the drilled sites are located in the North Pond region of the Atlantic Ocean $\left(22^{\circ} 45^{\prime} \mathrm{N}, 46^{\circ} 05^{\prime} \mathrm{W}\right)$ in $4414-4483 \mathrm{~m}$ water depth. This area is known from previous ocean drilling and site survey investigations as a site of particularly vigorous circulation of seawater in permeable 8 Ma basaltic basement underlying a $<300 \mathrm{~m}$ thick sedimentary pile. Understanding how this seawater circulation affects microbial and geochemical processes in the uppermost basement was the primary science objective of Expedition 336.

Basement was cored and wireline-logged in IODP Holes U1382A and U1383C. From Hole U1382A, which is only $50 \mathrm{~m}$ west of Deep Sea Drilling Project Hole 395A, we recovered $32 \mathrm{~m}$ of upper oceanic crust between 110 and 210 meters below seafloor (mbsf). Core recovery in basement was 32\%, yielding a number of volcanic flow units with distinct geochemical and petrographic characteristics. A unit of sedimentary breccia containing clasts of basalt, gabbroic rocks, and mantle peridotite was intercalated between two volcanic flow units and was interpreted as a rock slide deposit. From Hole U1383C we recovered $50.3 \mathrm{~m}$ of core between 69.5 and 331.5 mbsf (19\%). The basalts are aphyric to highly plagioclase-olivine-phyric tholeiites that fall on a liquid line of descent controlled by olivine fractionation. They are fresh to moderately altered, with clay minerals (saponite, nontronite, and celadonite), Fe oxyhydroxide, carbonate, and zeolite as secondary phases replacing glass and olivine to variable extents. In addition to traditional downhole logs, we also used a new logging tool for detecting in situ microbial life in ocean floor boreholesthe Deep Exploration Biosphere Investigative tool.

Sediment thickness was $\sim 90 \mathrm{~m}$ at Sites U1382 and U1384 and varied between 38 and $53 \mathrm{~m}$ at Site U1383. The sediments are predominantly nannofossil ooze with layers of coarse foraminiferal sand and occasional pebble-sized clasts of basalt, serpentinite, gabbroic rocks, and bivalve debris. The bottommost meters of sections cored with the advanced piston corer feature brown clay. Extended core barrel coring at the sediment/basement interface recovered $<1 \mathrm{~m}$ of brecciated basalt with micritic limestone. Sediments were intensely sampled for geochemical pore water analyses and microbiological work. In addition, high-resolution 
measurements of dissolved oxygen concentration were performed on the whole-round sediment cores. Major strides in ridge-flank studies have been made with subseafloor borehole observatories (CORKs) because they facilitate combined hydrological, geochemical, and microbiological studies and controlled experimentation in the subseafloor. During Expedition 336, two fully functional observatories were installed in two newly drilled holes (U1382A and U1383C) and an instrument and sampling string were placed in an existing hole (395A). Although the CORK wellhead in Hole 395A broke off and Hole U1383B was abandoned after a bit failure, these holes and installations are intended for future observatory science targets. The CORK observatory in Hole U1382A has a packer seal in the bottom of the casing and monitors/samples a single zone in uppermost oceanic crust extending from 90 to 210 mbsf. Hole U1383C was equipped with a three-level CORK observatory that spans a zone of thin basalt flows with intercalated limestone ( 70-146 mbsf), a zone of glassy, thin basaltic flows and hyaloclastites (146200 mbsf), and a lowermost zone ( 200-331.5 mbsf) of more massive pillow flows with occasional hyaloclastites in the upper part.

\section{Introduction}

The uppermost $\sim 500 \mathrm{~m}$ of basaltic ocean crust is fractured and permeable, harboring the largest aquifer on Earth. The oceanic crust is hydrologically active beneath at least $60 \%$ of the seafloor (Fisher, 2005), with a fluid flux through the crust that rivals global riverine input to the oceans (Wheat et al., 2003). Solutes and colloids (including microbes) circulate actively through the crustal aquifer, but the extent to which microbes colonize, alter, and evolve in subsurface rock is not known. A large fraction of ocean crust remains uncovered by sediments for millions of years on the flanks of mid-ocean ridges before being blanketed in the abyssal plains of the ocean and eventually subducted at trenches. These basement outcrops serve as "breathing holes" through which seawater can ventilate the ocean crust. Fluid flow in the crust is focused in specific areas where permeability is high-usually at the contacts of lava flows or in brecciated zones. In these intervals, the extent of rock alteration is increased, suggesting elevated intensity of seawater-rock interaction. It is well known that the geochemical changes associated with basalt alteration in the uppermost oceanic crust play an important role in setting ocean chemistry. It is unknown, however, what role microorganisms play in mediating this seawater-ocean crust exchange.
Laboratory studies, field examinations, and in situ field colonization and alteration experiments have shown that microbes are abundantly present and play an active role in rock alteration of exposed outcrops at the seafloor at low temperatures (e.g., Wirsen et al., 1993, 1998; Eberhard et al., 1995; Rogers et al., 2003; Edwards et al., 2003a, 2003b). In the subseafloor, the extent of direct participation in alteration by extant communities is not as clear. Abundant petrographic observations show that crust older than 100 Ma may harbor biological communities (e.g., Fisk et al., 1998). However, studies suggest that young subseafloor ocean crust may be the most redox active-and thereby the most likely to support active biological communities. Furnes et al. (2001) compared the degree of alteration in ocean crust aged 0-110 Ma. These data suggest that the majority of alteration features are established early and change little thereafter. Bach and Edwards (2003) compiled data concerning the oxidation state of the upper ocean crust. These data also suggest that oxidative ocean crust alteration occurs during the first 10 m.y. of ocean crust evolution. We therefore expect that hydrologically active, young ridge-flank crust is undergoing progressive oxidative alteration. If microorganisms metabolize the energy associated with the oxidation of $\mathrm{FeO}$ in the basalt, a sizeable microbial biomass may be supported by these oxidative alteration reactions (Bach and Edwards, 2003).

The principal science objective of Integrated Ocean Drilling Program (IODP) Expedition 336 was to address fundamental microbiological questions concerning the nature of the subseafloor deep biosphere in oceanic hydrological, geological, and bio-geochemical contexts. Primarily, we planned to study the nature of subseafloor microbiological communities in young igneous ocean crust in order to understand the role of these communities in ocean crust alteration and their ecology in hydrological and biogeochemical contexts. Specifically, we wanted to test the hypothesis that microbes play an active role in ocean crust alteration, while also exploring broad-based ecological questions such as how hydrological structure and geochemistry influence microbial community structures. We also intended to study the biogeography and dispersal of microbial life in subseafloor sediments.

The primary operational goal of Expedition 336 was the installation of subseafloor borehole observatories (CORKs) for long-term coupled microbiological, geochemical, and hydrological experiments. The study site for Expedition 336 is North Pond, a sediment pond on the western flank of the Mid-Atlantic Ridge, which is underlain by hydrologically active upper oceanic crust (Figs. F1, F2). The observatories will 
enable us to monitor conditions and study processes in situ after the drilling-induced disturbance and contamination of the borehole environment have dissipated. Sampling for microbiological and geochemical studies was conducted on basement and sediment cores retrieved from the CORKed holes and their immediate vicinities.

Our specific operational goals were to

1. Drill a basement hole to $\sim 565$ meters below seafloor (mbsf) at prospectus Site NP-1, core the bottommost $\sim 200 \mathrm{~m}$ of the basaltic crust, conduct downhole hydrologic (packer) tests and wireline logging, and install a multilevel CORK to conduct experiments in the deeper portions of the upper basement hydrological environment;

2. Drill a basement hole to $\sim 175 \mathrm{mbsf}$ at prospectus Site NP-2, core $\sim 70 \mathrm{~m}$ of the basaltic crust, conduct downhole hydrologic (packer) tests and wireline logging, and install a single-level CORK to conduct experiments in the uppermost basement hydrological environment;

3. Recover the existing CORK in Deep Sea Drilling Project (DSDP) Hole 395A, conduct downhole wireline logging, and install a multilevel CORK to conduct experiments in the deeper portions of the upper basement hydrological environment; and

4. Recover the thin sediment covers of prospectus Sites NP-1 (64 m) and NP-2 (85 m), Hole 395A (93 $\mathrm{m}$ ), and Ocean Drilling Program (ODP) Site 1074 (64 m) by drilling a single hole at each site with the advanced piston corer (APC).

The primary focus of operations during Expedition 336 was installation of the initial CORK experiments and preparation of the boreholes for subsequent long-term monitoring, experimentation, and observations using remotely operated vehicle (ROV) or submersible dive expeditions. CORKs are being used in perturbation and monitoring points for singleand cross-hole experiments using a recently developed novel in situ microbiological experimentation system, Flow-through Osmo Colonization System (FLOCS) (Orcutt et al., 2010, 2011a; also see www.darkenergybiosphere.org/resources/toolbox.html). An overview of the design, construction, and deployment of these CORKs is presented in a paper in this volume (Edwards et al., 2012).

Expedition 336 also included an enhanced education and outreach program intended to facilitate and communicate the excitement of scientific drilling and exploration to a broad audience, develop educational curricula, and generate products such as photographs, audio/visual media, and web-based materials to help achieve critical outreach goals.

\section{Background \\ Geological setting}

North Pond is an isolated, northeast-trending, $\sim 8 \mathrm{~km} \times$ $15 \mathrm{~km}$ sediment pond located on the western flank of the Mid-Atlantic Ridge at $22^{\circ} 45^{\prime} \mathrm{N}$ and $46^{\circ} 05^{\prime} \mathrm{W}$ (Figs. F1, F2). This area exhibits normal polarity that has been interpreted as magnetic Anomaly 4 (Melson, Rabinowitz, et al., 1979), suggesting a basement age between 7.43 and $8.07 \mathrm{Ma}$ using the geomagnetic polarity timescale of Cande and Kent (1995). The sediment cover is as thick as $300 \mathrm{~m}$ at the southernmost part of the pond. North Pond is bounded to the east and west by basement ridges as high as $2 \mathrm{~km}$. During DSDP Leg 45, two holes were cored with the rotary core barrel (RCB) at Site 395, penetrating the southeastern part of the sediment pond (Fig. F2; $22^{\circ} 45.35^{\prime} \mathrm{N}, 46^{\circ} 04.90^{\prime} \mathrm{W} ; 4484$ meters below sea level [mbsl]). A $93 \mathrm{~m}$ thick sediment sequence was cored in Hole 395, consisting of $89 \mathrm{~m}$ of foraminifer-nannofossil ooze underlain by $4 \mathrm{~m}$ of calcareous brown clays with manganese micronodules (Melson, Rabinowitz, et al., 1979). Basement penetration was $91.7 \mathrm{~m}$ (Hole 395) and $576.5 \mathrm{~m}$ (Hole 395A); a reentry cone and casing to basement were installed in Hole 395A. The basement lithology at this site is dominated by several units of massive and pillow lava flows (typically several tens of meters thick) that are separated by sedimentary breccia units, which resulted from mass wasting and contain cobbles of gabbro and serpentinized peridotite (Bartetzko et al., 2001; Melson, Rabinowitz, et al., 1979). A peridotite-gabbro complex several meters thick with brecciated contacts was cored in Hole 395 (Arai and Fujii, 1978; Melson, Rabinowitz, et al., 1979; Sinton, 1979).

Several expeditions have revisited Hole 395A for logging operations, packer testing, and borehole fluid sampling, including DSDP Leg 78B (Hyndman, Salisbury, et al., 1984), ODP Leg 109 (Detrick, Honnorez, Bryan, Juteau, et al., 1988), ODP Leg 174B (Becker, Malone, et al., 1998), and the French DIANAUT expeditions (Gable et al., 1992). Temperature and flow logs acquired during Leg 78B indicated rapid fluid flow $(\sim 1000 \mathrm{~L} / \mathrm{h})$ into Hole 395A (Becker et al., 1984) and low formation pressures, and this flow apparently continued for many years after drilling (Becker et al., 1998; Gable et al., 1992). Despite more than two decades of recharge into and through Hole 395A, the hydrology of the North Pond system has not been significantly affected (Becker et al., 1998). Geothermal (temperature and heat flow) surveys indicate that recharge occurs dominantly in the southeastern part of the basin, which is consistent with basement fluid flow generally directed to the northwest (Langseth et al., 1984). 
Comparison of lithologic and downhole electrical resistivity logs for Hole 395A suggests a series of distinct basalt flows (Bartetzko et al., 2001; Matthews et al., 1984). Each flow unit is characterized by an uphole decrease in electrical resistivity and an increase in gamma ray counts. Many of the low-resistivity intervals at the tops of the flow units correspond to recovery of cobbles or breccia, although recovery of the uppermost few hundred meters of basement was low. These results indicate that breccias developed between major flow units likely have high presentday permeability. These zones also exhibit high gamma ray counts, suggesting high $\mathrm{K}$ and $\mathrm{U}$ concentrations indicative of increased oxidative alteration. The correlation between alteration chemistry and permeability indicates that the basalt flow boundaries acted as fluid conduits throughout the hydrological history of the basement at Site 395 .

Downhole logging and packer results suggest that permeability at Site 395 decreases below 400 meters subbasement (msb) (Hickman et al., 1984), where temperature increases. In 1998, bulk density, temperature, and spontaneous potential (SP) downhole logs were collected in Hole 395A during Leg 174B (Becker, Malone, et al., 1998; Becker et al., 1998). The SP $\log$ is used in the petroleum industry to infer the locations of intervals in a borehole that receive or produce fluids. Deflections in the SP log also correspond to the tops of individual resistivity sequences, suggesting that these thin intervals, interpreted independently on the basis of resistivity and lithologic data to have higher porosity and permeability, are indeed the most hydrologically active. The typical ratio in thicknesses of the most and least hydrologically active sections of this borehole is on the order of $1: 10$ to $1: 100$, suggesting that most of the fluid that entered the formation surrounding Hole 395A passed through a small fraction of the exposed rock (Bach et al., 2004; Fisher and Becker, 2000).

During Leg 174B, Hole 1074A was cored near the northwestern margin of North Pond (Fig. F2). Temperature and geochemical profiles are diffusive, indicating there is no upward advection of basement fluids through the sediments, even in an area of local high heat flow (Becker, Malone, et al., 1998). This observation is consistent with the hydrologic model of Langseth et al. (1992, 1984), which indicates fluid flow is predominantly lateral beneath all of North Pond and recharge/discharge is taking place through basement outcrops that surround the basin. Most of the seawater recharge in Hole 395A is accommodated by aquifers in the uppermost $300 \mathrm{~m}$ of basement. Below this depth, temperature increases (Becker et al., 1998) and borehole fluid chemistry indicates significant chemical exchange with the rocks in the borehole walls (Gieskes and Magenheim, 1992; McDuff, 1984), which indicates a hydrological regime below $300 \mathrm{msb}$ that is less permeable and conducive to seawater circulation.

\section{Site survey data: seismic, bathymetric, heat flow, and sediment coring}

Seismic, sediment echo sounding, bathymetry, and heat flow measurements were recorded during R/V Maria S. Merian Cruise 11/1 in February/March of 2009 (Villinger and Cruise Participants, 2010). These data are presented in a report in this volume (see Schmidt-Schierhorn et al., 2012). A $12 \mathrm{kHz}$ swathbathymetry multibeam echo sounding system (Kongsberg EM120) was used to conduct a detailed bathymetric survey. Fourteen seismic lines with spacings between $<1$ and $3 \mathrm{~km}$ were collected across North Pond using a generator-injector gun and a $100 \mathrm{~m}$ long, 16-channel streamer. Eleven of these profiles are oriented southwest-northeast, and three run southeast-northwest. All heat flow measurements and sediment gravity coring were conducted on these seismic lines. Seismic two-way traveltime was used to estimate sediment thickness. The seismic record is poor at the boundaries of North Pond because the steep slopes of the bounding basement outcrops caused severe side echoes. In addition, it can be difficult to identify the exact basement/sediment interface because the rough basement topography does not produce a clear reflection pattern. Migrating the seismic data improves the imaging, and accurate sediment thicknesses for existing drill holes (395A and 1074B) can be calculated using a sediment velocity of $1700 \mathrm{~m} / \mathrm{s}$.

Fourteen gravity cores (up to $9.5 \mathrm{~m}$ in length) have been collected from North Pond between 4040 and $4480 \mathrm{mbsl}$ in areas of high heat flow in the northern and northwestern part of the basin. Preliminary interpretation is that the recovered sedimentary sequences represent pelagic sedimentation of claysized particles interrupted by abrupt deposition of foraminiferal sand layers. The presence of sharp, irregular bottom contacts and normal-graded bedding may indicate that these coarse-grained intervals are the result of gravity flows supplied from the surrounding slopes. Consistent with this interpretation, sand layers are commonly found at the deepest parts of the basin (>4300 mbsl) and are absent in cores retrieved from the less sedimented slopes of the basin.

Oxygen is the terminal electron acceptor in all gravity cores and hence the most sensitive indicator of microbial activity and fluid flow in the North Pond sediments. Dissolved oxygen permeates all of the cores recovered at all coring sites. A number of dissolved oxygen profiles appear to be affected by a 
deep secondary source of dissolved oxygen, causing them to increase toward the base of the core. Flow variability in the underlying basalt is hypothesized to cause these deeper increases in dissolved oxygen. This affect appears to be greatest in the northern part of the basin, which is why the sites for new CORKs were located there and not in the Site 1074 area, as proposed in the original drilling proposal.

\section{Scientific objectives}

Our objectives for Expedition 336 were to recover sediment and basement cores and to install new CORKs to address two major scientific questions:

\section{Where do deep-seated microbial communities come from?}

Viable, diverse, and distinct microbiological communities occur in deeply buried marine sediments, but the origin of these communities is currently unknown. One possibility is that microorganisms from overlying bottom seawater are a steady source of inoculum that seeds microorganisms (particle attached and free living) to sediments, allowing each sediment layer, no matter how deeply buried, to harbor (in principle) a population that derives from this initial deepwater inoculum. Another possibility is that microbial inoculum is provided by active transport (e.g., by vertical advective transport from the basement [passive transport] or by lateral active transport [swimming] from adjacent, older sediments following redox gradients). The latter hypothesis is consistent with known mechanisms (i.e., swimming by chemotactic response to chemical gradients or advective flow) and would explain how microbial communities persist in such nutrient-limited, deeply buried sedimentary sequences-that is, they evolved very specifically for this niche. However, this mechanism implies that sediments need to be in physical contact for effective inoculum transfer in order for these specialized niches to be exploited. Hence, an isolated sedimentary sequence may be inactive, dormant, or harbor evolutionarily distinct populations of microorganisms compared to sedimentary communities that receive the "ancient inoculum." North Pond is the ideal location to test these opposing hypotheses, which have important mechanistic implications concerning dispersal mechanisms in the deep biosphere and evolutionary consequences for microbial life on Earth. We will analyze the microbial communities in both deep sediments (obtained from cores taken during the expedition) and basement crustal fluids (obtained with the CORKs postexpedition).

\section{What is the nature of the microbial communities harbored in young ridge flanks, and what is their role in the ocean crust weathering?}

In the subseafloor, the extent of direct participation in weathering by extant communities is not clear. Abundant petrographic and geochemical data indicate that oxidative seafloor alteration occurs during the first 10-20 m.y. of crustal age and thereafter slows or ceases. These preliminary lines of evidence suggest that the most reasonable place to search for active subsurface microbial communities is in young ridge flanks $(<10 \mathrm{Ma})$. Most young ridge flanks lack a sediment cover, which presents difficulty for recovering intact upper ocean crust. One major exception is the Juan de Fuca Ridge flank. However, the high heat flow, rapid chemical reaction rates, and anaerobic conditions of this setting preclude using Juan de Fuca for our principal interest, which is to characterize more average, cold ridge flanks to reveal the role of microorganisms in promoting weathering on a global basis. Chemical reaction kinetics are inhibited at low temperatures, providing a window of opportunity for biological catalysts (Knab and Edwards, in press). The low heat flow ridge flank at North Pond represents an ideal model system for studying biologically mediated oxidative basement alteration. The work will also provide an excellent point of comparison for the studies taking place at the Juan de Fuca Ridge, which represents the warm, sedimented end-member in the global spectrum of ridge flanks.

\section{Operations plan}

The initial operations plan for Expedition 336 anticipated installation of CORKs at three sites (Hole 395A and prospectus Sites NP-1 and NP-2), with basement recovery at Sites NP-1 and NP-2 and sediment coring at all three. The initial plan (detailed in Edwards et al., 2010) had to be modified because of unforeseen events. In adjusting the operations plan, the overall strategy was tailored to achieve three objectives (ranked in order of decreasing priority): (1) install CORK observatories, (2) recover and log basement, and (3) recover sediments.

Operations began in Hole 395A, where the old-style CORK and thermistor string were removed before logging and depth-checking to $610 \mathrm{mbsf}$, introducing minimal amounts of surface seawater. A summary of logging results in Hole 395A is shown in Figure F3. We then attempted to install a new multilevel CORK with downhole and surface experiments, as illustrated in Figure F4. The final installation step 
failed when the wellhead was broken off as we tried to unlatch the CORK running tool, so a new hole (IODP Hole U1382A) was set up and drilled $50 \mathrm{~m}$ west of Hole 395A to install a shallow, single-level CORK observatory. Hole U1382A was drilled to 210 mbsf, penetrating $90 \mathrm{~m}$ of sediment and $120 \mathrm{~m}$ of basement. After coring was completed, $105.6 \mathrm{~m}$ of open borehole was logged (Fig. F5), and the hole was sealed with a $189 \mathrm{~m}$ long CORK completion string (Fig. F6).

We then planned to install the deep (500 msb) CORK observatory in the northern part of North Pond at prospectus Site NP-2. Our strategy was to set up the hole with 20 inch casing in the sediment cover, followed by 16 inch casing in upper basement. We then planned to deepen the hole with a $14 \% 4$ inch tricone bit to install $10^{3 / 4}$ inch casing to $\sim 140 \mathrm{msb}$. This strategy had to be changed, however, when IODP Hole U1383B, located $6 \mathrm{~km}$ north-northeast of Hole $\mathrm{U} 1382 \mathrm{~A}$, was lost as a result of the destruction of the tricone bit. The configuration of Hole U1383B is shown in Figure F7. Although this hole could not be deepened, the seafloor infrastructure and open-hole basement section are entirely available for an observatory installation. A new hole, U1383C, was spudded into basement and cased with $103 / 4$ inch casing to $60.4 \mathrm{msb}$. This hole was then RCB cored to $331.5 \mathrm{~m}$, logged (Fig. F8), and installed with a threelevel CORK (Fig. F9).

With our basement objectives largely achieved, we cored sediment with the APC in the vicinity of the CORK observatories, drilling two holes at Site U1383, one at Site U1382, and one at IODP Site U1384 (in the prospectus Site NP-1 area). We moved between locations without retrieving the drill string, APC cored to basement, and then extended core barrel (XCB) cored into basement for $\sim 1 \mathrm{~h}$. These cores were the focus of intensive microbiological and geochemical sampling.

\section{Hydrologic (drill string packer) testing}

In situ hydrogeologic testing is essential for quantifying crustal properties (transmissive and storage) that control ridge-flank hydrothermal circulation. We planned to use a drill string packer for hydrologic testing, which is reliable and relatively easy to integrate as part of a comprehensive program of basement drilling, sampling, and experiments. Tests in multiple depth intervals were to be conducted to discern the difference between test results at two depths and to quantify differences in hydrologic properties in discrete depth intervals.

The drill string packer was part of a bottom-hole assembly (BHA) that is compatible with logging so that a separate pipe trip was not required. Wireline logs were run before packer testing to assist with identifying zones suitable for packer element inflation (massive and in gauge). Tests followed the standard approach: (1) inflate and set the packer at the deepest setting point, (2) complete testing at that depth, and (3) deflate the packer, raise it to a shallower depth, and repeat the testing. The difference between test results at two depths can be used to quantify differences in hydrologic properties in discrete depth intervals. Tests are generally repeated at each testing depth, using two or more different pumping rates, to verify test response and formation properties.

Pressure data were generally collected using autonomous downhole pressure gauges that were suspended below a go-devil that was dropped into the packer when it was positioned at depth in the borehole. These gauges were recovered after the complete testing sequence had been run. The shipboard Rig Instrumentation System was used to record key pumping parameters: time, stroke rate, total number of strokes, BHA depth, and standpipe pressure, which is a backup for downhole pressure records.

\section{Logging/Downhole measurements}

Downhole measurements during Expedition 336 focused on characterizing crustal physical properties and defining structural and lithologic boundaries as a function of depth. In addition, wireline logging data were compared to results of laboratory analyses of discrete samples to help delineate alteration patterns, fracture densities, and structural orientations and determine how these correlate with fluid flow. These measurements complement core measurements by determining the thickness and structure of lithologic units in intervals where core recovery is poor. These logs were also critical for both shipboard hydrologic (packer) tests as well as for the precise depth placement of the CORK experiments.

Wireline tool strings were deployed in all basement holes and provided measurements including temperature, natural gamma ray, density, porosity, resistivity, sonic velocity, and microresistivity. Descriptions of the wireline tools and their applications are available at iodp.ldeo.columbia.edu/TOOLS_LABS/index.html.

We deployed adapted combinations of tool strings, including probes to measure borehole caliper, natural gamma ray (Hostile Environment Natural Gamma Ray Sonde [HNGS]), temperature (Modular Temperature Tool), and resistivity (Formation MicroScanner [FMS]) (the latter not in Hole 395A). Additionally, we employed the Deep Exploration Biosphere Investigative tool (DEBI-t) in a tool string. This tool was specifically designed and built for Expedition 336 to image the natural fluorescence of microbial communities within boreholes. 


\section{Summary of operational achievements}

Our achievements in meeting our operational goals are summarized below:

Drill a basement hole to $\sim 565$ mbsf at prospectus Site NP-1, core the lowermost $200 \mathrm{~m}$, log the hole, and install a multilevel CORK

We drilled a $331.5 \mathrm{~m}$ deep hole (U1383C) in the prospectus Site NP-2 area and cored/logged the lowermost $\sim 260 \mathrm{~m}$. A summary of the coring and logging results for Hole U1383C is presented in Figures F10 and F11. See the "Site U1383" chapter for more details (Expedition 336 Scientists, 2012b). A three-level CORK observatory was installed in Hole U1383C, with packers centered at 56, 142, and 196 mbsf (Fig. F9). Hole U1383B was penetrated to $89 \mathrm{mbsf}$ and was equipped with a reentry cone and ROV landing platform for future observatory science objectives.

\section{Drill a basement hole to $\sim 175$ mbsf} at prospectus Site NP-2, core $\sim 70 \mathrm{~m}$ of the basaltic crust, conduct hydrologic tests and wireline logging, and install a single-level CORK

A shallow, single-level CORK was installed in Hole U1382A, and this CORK will sample/monitor upper basement between 101 and 210 mbsf. A summary of the coring and logging results for Hole U1382A is presented in Figure F12. See the "Site U1382" chapter (Expedition 336 Scientists, 2012a) for more details.

\section{Recover the existing CORK in Hole 395A, conduct downhole wireline logging, and install a multilevel CORK}

The CORK installed in Hole 395A during Leg 174B, including the entire thermistor string, was successfully recovered. The hole was successfully logged with the new in situ deep ultraviolet (UV) fluorescence tool for detecting microbial life in ocean floor borehole (the DEBI-t); other logging data obtained include spectral gamma ray and temperature. A new three-level observatory was lowered into the seafloor; however, the CORK wellhead broke off, which will preclude our ability to conduct any downstream wellhead operations. Nevertheless, there is no conclusive evidence that the downhole portion of the observatory operations was significantly compromised, so a 4 y experimental run followed by downhole experiment/instrument recovery is still planned. Options for future use of the instrumentation in Hole 395A will be explored during upcoming ROV dives.
APC core the thin sediment cover in single holes at four sites (prospectus Sites NP-1 and NP-2, Hole 395A, and Site 1074)

ACP coring of sediments at Sites U1383 (prospectus Site NP-2; two holes), U1382 (near Hole 395A), and U1384 (prospectus Site NP-1) was achieved, and XCB coring retrieved short sections of the sediment/ basement interface from all locations. The sediments comprise nannofossil ooze, foraminiferal sand, and brown clay; Site U1382 also features layers with basalt and peridotite debris. The sediments were heavily sampled for microbiological and pore water analyses.

\section{Site summaries}

\section{Hole 395A}

Investigating coupled geochemical and microbial processes in active aquifers within the upper oceanic crust is the main science goal of Expedition 336, and the primary objective is initiating multilevel CORKs. We planned to install one observatory in the $664 \mathrm{~m}$ deep Hole 395A in the southeastern part of North Pond. Hole 395A was drilled during Leg 45 in 19751976, was logged repeatedly, and was then equipped with a first-generation CORK in 1997 during Leg 174B (Becker, Malone, et al., 1998). Hole 395A is located in an area of exceptionally low conductive heat flow (Langseth et al., 1992) due to cooling of the uppermost basement by cold seawater, which recharges basement and is inferred to flow underneath the sediment cover in a northerly direction.

At the beginning of our operations at Site 395, the old Leg 174B CORK, including the entire $603 \mathrm{~m}$ internal string with thermistors, a data logger, and pressure sensors, was successfully pulled out of Hole 395A and secured on board the R/V JOIDES Resolution. The pressure and temperature data were downloaded, the thermistors were cut out of the string, and sections of the string were sampled for microbiological analyses. Further microbiological samples were obtained from the CORK's ROV platform and wellhead elements. The hole was then logged with a new in situ deep UV $(<250 \mathrm{~nm})$ fluorescence tool for detecting microbial life in ocean floor boreholesthe DEBI-t. Other logging data obtained included spectral gamma ray and temperature. A rock ledge in the borehole at $\sim 180 \mathrm{mbsf}$ had to be bridged by lowering the logging bit to $198 \mathrm{mbsf}$, but then an open-hole section of $405.7 \mathrm{~m}$ was logged (total depth reached was $603.5 \mathrm{~m}$ ). The lowermost $\sim 50 \mathrm{~m}$ of the hole was not logged because it was found to be filled with rubble during Leg 174B. The logging results are consistent with the data obtained by 
Bartetzko et al. (2001) and allow the distribution of massive basalt, pillow basalts, altered lava flows, and rubble zones (sedimentary breccia and hyaloclastite) to be distinguished.

A $530 \mathrm{~m}$ long, multilevel CORK observatory was assembled to perform long-term coupled microbiological, biogeochemical, and hydrological experiments. Assembling the observatory entailed preparing osmotically driven fluid samplers, microbial incubation experiments, seven temperature sensors, and two oxygen sensors. Packers at midpoint depths of 111,149 , and 463 mbsf were installed to isolate the borehole into three intervals characterized by different thermal and fluid flow regimes. Umbilicals containing fluid sampling lines attached to the outside of the CORK casing were designed to reach depths of 120, 430, and 506 mbsf. OsmoSamplers for fluid geochemistry and microbiology were lowered on Spectra rope inside the slotted or perforated CORK casing to sample four intervals: 112-140, 233-261, 409-438, and 491-527 mbsf. The CORK wellhead was instrumented with sensors for monitoring pressures in the four zones isolated by packers and with OsmoSamplers for retrieving fluid samples from the lowermost zone.

The assembly and installation proceeded well until the CORK head broke off during the final step of releasing the CORK running tool. The CORK head experienced forces that bent the wellhead and severed its 5 inch pipe $\sim 4 \mathrm{~m}$ below the top of the reentry cone, parting the Spectra rope and the umbilicals and leaving the downhole tool string in place. On the basis of the portion of the CORK wellhead recovered, the upper end of the remaining 5 inch diameter cup packer subassembly near the seafloor (5 inch pipe mandrel) is not completely rounded; however, it may be open enough to allow recovery of the internal downhole samplers, sensors, and experiments in the future. Several stainless steel tubes likely extend above the cup packers and the top of the 5 inch casing. Damage to the stabilizing fins above the cup packers suggests that they may have been too large in diameter to enter the throat of the reentry cone (DSDP documentation indicated a 24 inch diameter, now thought to be less), which may have been the root cause of the installation failure. Indeed, similar damage was observed on the Leg 174B CORK that was recovered (it, too, did not fully land). The CORK pressure logging system was recovered along with the broken-off wellhead. The recorded data do not definitively resolve whether the downhole CORK packers actually inflated; however, no data are otherwise available to suggest that the packers did not inflate as intended. A plan is being formulated to recover the downhole instrument string in $4 \mathrm{y}$ with an ROV.

\section{Site U1382}

Hole U1382A was drilled $50 \mathrm{~m}$ west of Hole 395A at $22^{\circ} 45.353^{\prime} \mathrm{N}, 46^{\circ} 04.891^{\prime} \mathrm{W}$, in $4483 \mathrm{~m}$ water depth. The primary objective for Hole U1382A was to install a CORK to perform long-term coupled microbiological, biogeochemical, and hydrological experiments in uppermost basaltic crust in this area of very low conductive heat flow. Coring and downhole logging of basement were also conducted.

After the reentry cone with $53 \mathrm{~m}$ of 16 inch casing was jetted in, the hole was deepened by drilling with a $143 / 4$ inch tricone bit to $110 \mathrm{mbsf}$ without coring. Basement was encountered at $90 \mathrm{mbsf}$, and $3 \mathrm{~m}$ of basement was penetrated in $30 \mathrm{~min}$. The interval from 93 to 99 mbsf was drilled very quickly and is inferred to be sediment; however, the underlying formation to $110 \mathrm{mbsf}$ was drilled slowly $(2-3 \mathrm{~m} / \mathrm{h})$ without significant torque. Casing (103/4 inch) was installed and successfully cemented to 102 mbsf. RCB coring recovered basement from 110 to 210 mbsf (Cores 336-U1382A-2R through 12R). In total, $32 \mathrm{~m}$ of core was retrieved, with recovery rates ranging from $15 \%$ to $63 \%$. This succession resembles the lithostratigraphy encountered in Holes 395 and 395 A and provided excellent sampling material for various microbiological and petrologic studies.

The shipboard petrologists divided the core into eight lithologic units, comprising numerous subunits. Major unit boundaries are defined by contacts between massive and pillowed flows and interlayered sedimentary units. Each major lava flow unit consists of several cooling units, which are recognized by glassy or variolitic margins or marked changes in grain size. Results from thin section studies reveal a large range of grain sizes (glassy to medium grained) and diverse textures (aphanitic to subophitic or intersertal). Basalts are either aphyric or plagioclase-olivine-phyric and have $<3 \%$ vesicles. Phenocryst contents range up to $25 \%$, with plagioclase being more abundant than olivine. All of the volcanic rocks recovered from Hole U1382A are affected only by low-temperature alteration by seawater, manifesting as replacement of groundmass and phenocrysts, vesicle filling, glassy margin replacement, and vein formation with adjacent brown alteration halos. Chilled margins often show advanced palagonitization, which develops as blotchy alteration texture following the primary variolitic texture of the mesostasis. The extent of alteration ranges up to $20 \%$, with clay (smectite and celadonite) being the most abundant secondary phase, followed by Fe oxyhydroxides and minor zeolites and carbonates. The recovered section has between 13 and 20 veins $/ \mathrm{m}$, with vein thickness being usually $<0.2 \mathrm{~mm}$. A sedimentary unit in Cores 336-U1382A- 
8R and 9R features a variety of clasts, including plutonic and mantle rocks. The peridotites are weakly serpentinized harzburgites and lherzolites with a protogranular texture. The intensity of deformation of the gabbroic lithologies ranges from undeformed to mylonitic. Minor cataclastic deformation of the peridotites has led to the development of carbonatefilled vein networks, along which the rocks have been subjected to oxidative alteration, resulting in the breakdown of olivine to clay, oxide, and carbonate.

Physical properties measurements reveal typical $P$ wave velocities for these lithologies and a correlation between sonic velocity and porosity of the basalt. Elevated potassium and uranium concentrations in the oxidatively altered part of the core were revealed by natural gamma radiation (NGR) core scanning. Thermal conductivity also reflected the typical values associated with basalt and peridotite and showed small variations with depth.

Whole-rock geochemistry analyses reveal systematic differences in compositions between aphyric and porphyritic basalt, which are due to plagioclase accumulation in the porphyritic basalt. The aphyric basalts show a liquid line of descent that is controlled by the fractional crystallization of olivine. As the extent of alteration increases, loss on ignition values and potassium concentrations also increase. Immobile trace element ratios $(\mathrm{Zr} / \mathrm{Y}$ and $\mathrm{Ti} / \mathrm{Zr})$ indicate that parental magma compositions for the basalts above and below the sedimentary unit are different from each other. Petrographically and geochemically, the basalts correspond to the uppermost lithologic units identified in Hole 395A. Likewise, a sedimentary unit with varied plutonic and mantle rocks was also observed in Hole 395A.

A primary objective of basement coring was to obtain samples for microbiological analysis. We collected 46 hard rock and 2 sediment whole-round samples for these studies ( $11 \%$ of core recovered). Samples were preserved for ship-based (deep UV fluorescence scanning, culturing and enrichment, and fluorescent microsphere analysis) and shore-based (DNA and RNA analysis, fluorescence in situ hybridization (FISH), cell counting, and isotopic analysis) studies. Generally, 1-3 microbiology hard rock samples were collected from every core section. Hard rock samples span a range of lithologic units, alteration states, and presence of chilled margins, and some contain veins or fractures. Additionally, a few recovered plastic bags that held the fluorescent microsphere solutions in the core catcher were collected as a contamination check via DNA analysis.

An open-hole section of $105.61 \mathrm{~m}$ was logged over a period of $\sim 19.5 \mathrm{~h}$ with two tool strings (the adapted microbiology combination I [AMC I] and the FMS-
HNGS). Downhole log measurements include natural total and spectral gamma ray, temperature, density, electrical resistivity, electrical images, and deep UVinduced fluorescence (acquired with the new DEBI-t). The borehole remained in good condition throughout logging, and no obvious tight spots were encountered in open hole. Integration of core and log measurements and observations showed excellent correspondence between potassium concentrations provided by shipboard NGR, the spectral gamma ray logging tool, and whole-rock geochemical analyses. FMS data were combined with images of the external surfaces of whole-round cores. Prominent veins with alteration halos in cores from the massive flows were matched with fractures in the FMS images. Also, logging results constrain the depth of the peridotite interval from 165 to 167 mbsf (based on density and low $\mathrm{K} / \mathrm{U}$ ratios).

Downhole hydrologic (packer) tests failed because ship heave up to $3 \mathrm{~m}$ prevented the packer from sealing in the casing for $>10 \mathrm{~min}$.

A CORK to monitor and sample a single interval in uppermost basement was successfully installed in Hole U1382A. The $210 \mathrm{~m}$ deep hole was sealed with a $189 \mathrm{~m}$ long CORK with nine external umbilicals and a retrievable internal instrument string. The umbilicals include one for pressure monitoring, two for microbiological sampling, and six for fluid sampling. The retrievable internal instrument string comprises several osmotic pump-driven samplers for basement fluids and microorganisms as well as enrichment experiments, an oxygen probe, and a thermistor with data recorder. The samplers and probes extend from 146 to 174 mbsf and are kept in position by a $150 \mathrm{lb}$ sinker bar at $177 \mathrm{~m}$. A pressure gauge and a fastpumping OsmoSampler are situated in the wellhead and monitor/sample fluids from 162 mbsf.

\section{Site U1383}

Site U1383 (prospectus Site NP-2) is located $5.9 \mathrm{~km}$ northeast of Site U1382 in an area of elevated conductive heat flow in $4414 \mathrm{~m}$ water depth. The primary objective at Site U1383 was to install a multilevel CORK for long-term coupled microbiological, biogeochemical, and hydrological experiments in uppermost basaltic crust. Basement coring, downhole logging, and hydrologic experiments were also planned.

Hole $\mathrm{U} 1383 \mathrm{~B}$ at $22^{\circ} 48.1328^{\prime} \mathrm{N}, 46^{\circ} 03.1556^{\prime} \mathrm{W}$, was prepared for drilling $500 \mathrm{~m}$ into basement by installing a reentry cone with 20 inch casing extending to 35 mbsf. We then prepared the hole for 16 inch casing by drilling an $18 \frac{1}{2}$ inch hole to $68 \mathrm{mbsf}$; the sediment/basement interface is at 53 mbsf. After installing and cementing the 16 inch casing to $54 \mathrm{mbsf}$, 
we started to prepare the hole for $10^{3 / 4}$ inch casing by drilling a hole into basement with a $14 \%$ inch tricone bit. We decided to abandon Hole U1383B after this tricone bit failed at $89.8 \mathrm{mbsf}$, resulting in large parts of the bit being left in the hole. Although we did not choose to deepen this hole, it remains a viable CORK hole because it has a completely functional reentry cone and casing system with $\sim 35 \mathrm{~m}$ of accessible basement. A ROV landing platform was therefore installed in the reentry cone to facilitate future ROV operations, which will include installation of an instrumented plug in Hole U1383B.

Hole U1383C $\left(22^{\circ} 48.1241^{\prime} \mathrm{N}, 4^{\circ} 03.1662^{\prime} \mathrm{W}\right)$ was started at the site of the original jet-in test, $25 \mathrm{~m}$ southwest of Hole U1383B. The primary objective was installing a multilevel CORK in the uppermost $\sim 300 \mathrm{~m}$ of basement. The ultimate configuration of the CORK in Hole U1383C was to be determined by the depth of basement penetration and the downhole logging results. A reentry cone with 16 inch casing was installed to $34.8 \mathrm{mbsf}$, and a $14 \% / 4$ inch hole was drilled to $69.5 \mathrm{mbsf}$ for the $103 / 4$ inch casing string. The sediment/basement interface was encountered at 38.3 mbsf. After cementing the $10^{3} / 4$ inch casing at 60.4 mbsf, drilling in Hole U1383C proceeded with a RCB bit from 69.5 to 331.5 mbsf. From this $262 \mathrm{~m}$ long interval, $50.3 \mathrm{~m}$ of core was recovered (19.2\%). Rocks are glassy to fine-grained basalts with variable phenocryst (plagioclase and olivine) contents. Three major lithologic units were distinguished on the basis of primary texture and phenocryst abundance. From 69.5 to $127 \mathrm{mbsf}$, the core consists of microcrystalline to fine-grained, sparsely plagioclasephyric basalt with abundant glassy margins and numerous intervals of hard interflow limestone. From 127 to 164 mbsf, massive plagioclase-olivinephyric basalts occurs, occasionally hosting limestone (with and without basalt clasts) as fracture fill. Below 164 mbsf, glassy to variolitic to cryptocrystalline basalts (most likely pillow flows) predominate, and limestone is largely missing. Each of these three main lithologic units is divided into numerous subunits on the basis of hyaloclastite layers and rare tectonic breccias. The overall abundance of glass is noticeably greater than that in Hole U1382A, and the extent of palagonitization ranges from weak to moderate. Basalts are avesicular to sparsely vesicular and show vesicle fills of clay, zeolite (mainly phillipsite), calcium carbonate, and Fe oxyhydroxide. Brownish alteration halos commonly track veins filled with clay or carbonate and zeolite. Within Unit 3, a gradational change from glassy, to variolitic with abundant hyaloclastite layers, to more massive microcrystalline, to fine-grained basalt with rare glassy margins can be observed.
Although the hyaloclastites are noticeably palagonitized throughout the hole, the extent of background alteration appears to decrease downsection. Vein densities average 33 veins/ $\mathrm{m}$ and increase somewhat downsection to 50 veins $/ \mathrm{m}$. Zeolite veins are abundant in the upper section of the drilled interval, whereas carbonate veins predominate in the lowermost part. Sparse vesicles are filled with zeolite and clay.

Physical properties measurements reveal tight correlations between sonic velocity, density, and porosity of the basalt. These correlations reflect changes in physical properties as a result of low-temperature alteration. In basalts with up to $40 \%$ alteration, $P$-wave velocities and bulk densities as low as $4750 \mathrm{~m} / \mathrm{s}$ and $2.43 \mathrm{~g} / \mathrm{cm}^{3}$ were recorded. These most altered basalts also show exceptionally high porosities (up to 16.6\%). Despite the locally high alteration intensity, NGR core scanning revealed fairly low average potassium and uranium concentrations (e.g., $0.19 \pm 0.05 \mathrm{wt} \% \mathrm{~K}$ ). Fresh basalts show physical properties and K concentrations typical for mid-ocean ridge basalt.

Whole-rock geochemical data show that basalts from Units 1 and 2 systematically differ in $\mathrm{Zr} / \mathrm{Y}$ and $\mathrm{Zr} / \mathrm{Ti}$ ratios from basalts from Unit 3. The compositional variability in the different units is primarily due to fractionation of olivine, but some trends (gain of $\mathrm{K}$, loss of $\mathrm{Mg}$ ) are also related to increased alteration intensity. The porphyritic basalts do not show the distinct plagioclase accumulation signature revealed in similar basalts from Holes U1382A and 395A. Correlations between Site U1383 and Sites U1382 and 395 based on geochemical composition cannot be made for individual flow units, indicating that the sites belong to different volcanic centers that were fed by mantle sources with variable compositions.

Hard rock samples for microbiological analysis were collected from every RCB core from Hole U1383C. Roughly $12 \%$ (6.11 m total) of core recovered from Hole U1383C was taken as whole-round samples from the core splitting room and dedicated to microbiological analysis. The 79 hard rock microbiology samples span a range of lithologic units, alteration states, and presence of chilled margins, and some contain at least one vein or fracture. Additionally, a few background contamination samples were collected for shore-based DNA analysis, including recovered plastic bags that held the fluorescent microsphere solutions in the core catcher.

Samples recovered were preserved for shore-based DNA and RNA analysis, shore-based FISH and cell counting, ship-based culturing and enrichments, shore-based isotopic analysis, and ship-based fluorescent microsphere analysis. Microspheres were used during all coring operations to help in evaluating core contamination. The enrichment and cultivation 
experiments initiated include carbon fixation incubations; carbon and nitrogen cycling experiments; enrichments for methanogens, sulfate reducers, sulfide oxidizers, and nitrate-reducing iron-oxidizing bacteria; and enrichments for heterotrophic metabolisms.

Deep UV ( $<250 \mathrm{~nm})$ scanning of hard rock materials was used to identify sample regions with concentrations of biomass and organic material.

Wireline logging data include natural total and spectral gamma ray, density, compressional velocity, electrical images, and deep UV-induced fluorescence (acquired with the new DEBI-t) of a $274.5 \mathrm{~m}$ section of open hole. Lithologic Unit 1 is characterized by variable caliper, density, and sonic velocity values. Gamma ray intensities are generally low but increase in the bottom part of the unit. Lithologic Unit 2 has a uniform caliper and high densities and apparent sonic velocities and shows high-resistivity massive flows with fractures in the FMS images. The upper section of lithologic Unit 3 (153-166 mbsf) is characterized by decreases in density, apparent resistivity, and velocity and an increase in gamma ray intensity. This interval corresponds to thin flows with interpillow/ flow sediments and tectonic breccia. From $166 \mathrm{mbsf}$ to the bottom of the hole, the logging data reveal fairly uniform values for density, velocity, and apparent resistivity. Areas with peaks in gamma ray intensity correspond to intervals with abundant hyaloclastite in the recovered core (in particular around $175 \mathrm{mbsf}$ and from 220 to 250 mbsf).

Drill string packer experiments were attempted in Hole U1383C to assess the transmissivity and average permeability of open-hole zones bounded by the bottom of the hole at $331.5 \mathrm{mbsf}$ and three different packer inflation seats at 53,141, and 197 mbsf. The packer experiments were not successful.

In preparation for the CORK observatory, Hole U1383C was cased through the $38.3 \mathrm{~m}$ thick sediment section with $103 / 4$ inch casing to 60.4 mbsf and through a $143 / 4$ inch rathole to $69.5 \mathrm{mbsf}$. After the hole was RCB cored to 331.5 mbsf and cleaned in five wiper trips, there was no noticeable fill, which was verified during logging. The CORK screens and downhole instrument string targeted three zones, selected mainly on the basis of recovered core and the caliper log. An upper zone extends from the combination packer and landing seat at 58.4 mbsf in the casing to the first open-hole packer and landing seat at 145.7 mbsf. Within this section the miniscreens are centered at 100 mbsf, with the slotted portion of the casing extending from 76 to 129 mbsf. The middle zone extends to an open-hole packer and landing seat at 199.9 mbsf. Within this section the screens are centered at $162 \mathrm{mbsf}$, with the slotted casing extending from 146 to 181 mbsf. The deep zone reaches to the bottom of the hole (331.5 mbsf) with miniscreens centered at 203 mbsf. The miniscreens are connected to the wellhead by five umbilicals with stainless steel or Tefzel internal tubing that are strapped to the outside of the casing. The downhole tool string consists of six different OsmoSampler packages, two dissolved oxygen sensors and recorders (one in the shallow zone and one in the middle zone), two miniature temperature recorders, sinker bars, sealing plugs, and interspersed sections of $3 / 8$ inch $(0.95 \mathrm{~cm})$ Spectra line. The wellhead is instrumented with a pressure logger monitoring each of the three horizons and bottom seawater and a fast-flow OsmoSampler with both standard and microbiological sampling packages. The CORK extends to $247.6 \mathrm{mbsf}$, yet leaves the bottom portion of the hole open for future logging and access (247.6-331.5 mbsf).

\section{Sediment and basement contact coring (Holes U1383D, U1383E, U1382B, and U1384A)}

This section summarizes the results of APC sediment coring and $\mathrm{XCB}$ coring of the sediment-basement transition at Sites U1383 (prospectus Site NP-2), U1382 (near Hole 395A), and U1384 (prospectus Site NP-1).

In Hole U1383D, $44.3 \mathrm{~m}$ of sediment was cored, of which the lowermost $1 \mathrm{~m}$ was XCB cored through basalt and limestone-cemented breccia $(0.76 \mathrm{~m}$ of basement was recovered). At nearby Hole U1383E, $44.2 \mathrm{~m}$ of sediment and $1 \mathrm{~m}$ of basaltic basement was cored ( $0.3 \mathrm{~m}$ of basement was recovered). The basalts are aphyric and slightly to moderately altered. They are distinct from the uppermost basaltic flow that was RCB cored in Hole U1383C and hence represent a different lithologic unit.

Hole U1382B was drilled midway between Holes 395A and U1382A. A total of $90.0 \mathrm{~m}$ of sediment was APC cored, and another $8.8 \mathrm{~m}$ was cored with the $\mathrm{XCB}$, recovering a piece of basalt and countless millimeterto centimeter-sized pebbles of completely altered plutonic and ultramafic rocks at the basement/ sediment interface. These rocks are interpreted to be part of the sedimentary breccia overlying the massive basalt of Unit 1 cored in Hole U1382A.

Coring in Hole U1384A recovered $93.5 \mathrm{~m}$ of sediment overlying $0.58 \mathrm{~m}$ of basalt and limestone-cemented breccia. The basalts are aphyric and sparsely vesicular with glassy to variolitic to microcrystalline groundmass. They are between $3 \%$ and $10 \%$ altered and display brown alteration halos along clay veins and fractures.

The sediments at all sites consist of foraminifer nannofossil ooze with layers of foraminiferal sand. The bottom several meters of the sedimentary pile are brown and appear rich in clay. Sediments from Hole U1382B show moderately rounded rock fragments concentrated in layers or dispersed in the ooze. 
These fragments range from coarse sand to pebble in grain size and consist of serpentinized mantle peridotite, gabbro, troctolite, and basalt. Both XCB cores from Hole U1382B also contain coarse sediment with predominantly serpentinite clasts, including soapstone and talc-tremolite schist. The occurrence of these rock fragments is consistent with the polymict sedimentary breccia recovered during basement drilling in Holes 395A and U1382A. The deformed and metasomatized lithologies encountered in Hole U1382B corroborate the hypothesis that this material was transported to the Site U1382 area in North Pond by mass wasting events and that its source is an oceanic core complex, probably in the southern rift mountains. Layers of foraminiferal sand are abundant in all holes and many show erosional bases and normal-graded bedding, suggesting that they represent deposits of turbidity currents.

Each of the four holes cored was intensively sampled for microbiological and interstitial water analyses. The sampling program was similar for each hole. In total, we collected 167 whole-round samples for interstitial waters and 691 whole-round samples for microbiological analysis. Sampling density was increased in the bottom sections. Pore waters in these basal sediments are dominated by diffusion of components from the basement fluids into the sedimentary pile, and they allow estimation of basement fluid compositions by extrapolation. Whole-round cores were preserved for shore-based molecular analysis to provide a detailed description of the microbial community. Ship-based enrichment cultures were established to enrich for multiple metabolic functional groups. These cultures will be analyzed on shore for both metabolic activity and community composition. Sediment sections remaining after whole-round sampling were analyzed for oxygen concentration using optodes. Hard rock samples were sectioned and allocated following previous strategies established during the hard rock drilling phase of the expedition. Multiple basalt samples were provided for RNA/DNA, geochemistry, and culture analysis.

An extensive high-resolution physical properties data set was obtained for all holes. This data set includes whole-round, split-core, and discrete measurements of magnetic susceptibility, velocity, density, porosity, NGR, and resistivity.

\section{Atmospheric and surface-water microbiology studies}

Investigations of atmospheric and surface-water microbiology were conducted by a shipboard atmospheric microbiologist during Expedition 336 for a project titled "Long-range transatlantic transport of microorganisms in clouds of African desert dust: a study of atmospheric microbiology, chemistry, and the influence of desert dust on surface-water microbial ecology." A full description of this project and the shipboard results are presented in a paper in this volume (Griffin, 2012).

Atmospheric samples were collected in transit and while on-station daily from 19 September to 11 November 2011 (54 sample days). As a result of incubation-period constraints, the resultant report included data collected from 19 September to 1 November (44 sample days). These data indicate that atmospheric particulate matter moving over the Atlantic Ocean from Europe and Africa carries culturable microorganisms and that colony-forming unit concentrations in these air masses correlate with particulate concentrations. Further, these data demonstrate a "fertilization effect," where surface-water prokaryote concentrations correlate to near-surface atmospheric particulate concentrations. Numerous episodes of African dust presence occurred in the near-surface atmosphere over the period of the study. Many of the high-volume membrane filter particulate/aerosol loads produced dark and light orange coloration similar to that of desert surface soils of the Sahara and Sahel. These samples will be evaluated postexpedition for chemical and biological composition. Dust deposition was so heavy at times that dust particles pooled into naturally occurring wind traps located on the roof of the R/V JOIDES Resolution, which enabled collection into resealable plastic bags. Particle count data and the strength of correlations with surfacewater communities and atmospheric communities will be evaluated again after chemical analyses of the high-volume filters. These analyses will be needed to verify sources and to determine if the particulate loads on the light gray to dark gray filters are an artifact of diesel exhaust or biomass burning in Europe or Africa. These data, along with data such as wind speed, wind direction, and ship orientation, will be valuable in determining which air masses and their sources influenced these communities. Obviously, additional (shore-based) data and more careful interpretation are needed to accurately evaluate the true extent of the observed relationships outlined here and for those yet to be determined. Additional shore-based studies will include the identification of isolates and nonculture-based studies to determine community composition and the reaction of various species of bacteria to surface-water dust deposition.

\section{Education, outreach, and communication objectives}

Expedition 336 sailed with one onboard education officer, but several of members of the science party 
also conducted education, outreach, and communications (EOC) activities while on board. The education officer was an elementary school teacher with a background in marine biology, as well as a marine science web designer. Four shipboard microbiologists also initiated education and outreach activities.

The primary goals of the Expedition 336 EOC effort were to (1) connect shipboard scientific, technical, and engineering personnel with nonspecialists on shore; (2) develop K-12 curricula related to the expedition's scientific objectives and general science, technology, engineering, and math topics; (3) create and distribute multimedia materials (written, photographic, and video) related to expedition objectives and accomplishments; (4) help Expedition 336 scientific personnel learn to communicate the excitement of their research and other activities to an audience of nonscientists; and (5) teach the onboard education officer about the scientific foundations of the mission and the technical tasks involved in deep-sea scientific drilling in order to create a solid understanding of the scientific process that can then be communicated through her own formal and informal education efforts.

\section{Education, outreach, and communication summary}

The shipboard EOC team advanced the scientific goals of the expedition and of IODP by communicating the importance of scientific ocean drilling to a broad external audience and engendering understanding and enthusiasm for scientific exploration, ocean drilling, and subseafloor observatories. This was accomplished in partnership with the science party. Toward this objective, the team worked with custom websites, blogs, up-to-the-minute social media, and live video interactions with schools and museums.

More than 43 blog posts in English, Spanish, and French were added to joidesresolution.org/ (a United States Implementing Organization website oriented toward a nonscientific audience) by seven authors, including the onboard education officer, scientists, engineers, and technical staff. Subjects included shipboard life, operations and deep-sea drilling, engineering and CORK observatories, microbiology, and math. Blog posts were viewed an average of 288 times each. In addition, four outside blogs/websites were published by onboard scientists. Katrina Edwards wrote about our expedition on the Expeditions blog at Scientific American (blogs.scientificamerican.com/expeditions/); this blog was also published on the Center for Dark Energy Biosphere Investigations (C-DEBI) website (www.darkenergybiosphere.org/return-to-northpond/). Beth Orcutt wrote about microbiology on the Adopt-a-Microbe project website (aam.darkenergybiosphere.org/), Amanda Haddad wrote for a special needs audience on the Classroom Connection website (www.darkenergybiosphere.org/classroomconnection/), and Heath Mills wrote a blog about Mid-Atlantic Ridge microbiology hosted on Texas A\&M's College of Geosciences website (georesearch.tamu.edu/blogs/ microbiology/). Altogether, more than 115 blog posts were published about Expedition 336.

Visits to the JOIDES Resolution website and page views within the site both increased significantly during Expedition 336. During the 6 weeks prior to the expedition there were 4,632 visits, resulting in 15,651 page views. During the first 6 weeks of the expedition, there were 11,044 visits (a 138\% increase) and 42,217 page views (a 170\% increase). Website viewership has increased since last year as well, possibly indicating that each expedition retains some followers and that networking has resulted in increased awareness. During the same 6 week period during 2010 (mid-September through October), there were 8,448 visits and 34,867 page views. Viewership during this expedition demonstrated a $31 \%$ increase in visits and a $21 \%$ increase in page views compared to last year (Fig. F13).

The expedition page on the JOIDES Resolution website contained information about the scientific background and objectives of the expedition, videos about different aspects of the instrumentation and operations, links to microbiology news articles, information about participants, and a daily math problem related to the expedition. Teachers and other participants in EOC activities were directed to this page for general information on the expedition prior to videoconferences. As a result, this page received over 3,165 views during the first 6 weeks of the expedition, which is $7.5 \%$ of the total 42,217 page views.

The onboard education officer, with the assistance of scientific, technical, and engineering staff, conducted 47 live ship-to-shore video interactions, reaching more than 1800 participants ranging from third grade through university (Table T1). The majority of these interactions were 30-45 min conferences with individual or combined elementary, middle, and high school classes ranging in size from 5 to 300 students. Schools were located across the United States in 13 states, as well as in France, Spain, England, Australia, and the Virgin Islands. Thirteen of the broadcasts were arranged on board with groups that had a direct connection to scientists on board. Four live seminars were broadcast from the ship to scientists' home universities and conferences in France, England, and the United States (Texas and Florida). A total of 20 scientists, engineers, and technical staff 
members participated in the live broadcasts, both as hosts and as guests during the question-and-answer portion of the videoconferences.

Further information will be collected through user surveys, but initial responses from participating teachers indicate a generally positive response to the fast-paced virtual tours of shipboard laboratories and interviews with scientific, technical, and engineering staff. Teachers indicated that through participation in the videoconferences, their students learned more about geoscience content, marine careers, the JOIDES Resolution, and how science works.

Social media sites Facebook and Twitter were used to communicate up-to-the-minute information from the JOIDES Resolution. Increased traffic on both sites indicated a following of the expedition. In the month prior to the expedition, the JOIDES Resolution Facebook page had an average daily reach of 245 unique users, and an average of 20 users who engaged with the page on a daily basis. During the first 7 weeks of Expedition 336, this increased to an average daily reach of 835 unique users, including an average of 62 users engaging daily. During the expedition, more than 135 posts were made to the Facebook page, with an average viewership of 641 unique users. Photos were consistently the posts that engaged the most users, whereas posts tagged with other organizations' pages (such as those made during Earth science week that were connected to the "Earth Science Week" Facebook page with a tag) had the most reach. A number of short videos were produced during the expedition, posted to YouTube and Vimeo, and shared via social networks. Subjects varied, but included shipboard life, expedition progress, drilling operations, and sampling procedures.

The Adopt-A-Microbe project, which was initially developed during IODP Expedition 327 to engage learners in microbiology research at the bottom of the ocean (Orcutt et al., 2011b), was rerun during Expedition 336. In this project, scientists on board the JOIDES Resolution, led by microbiologist Beth Orcutt, interacted with shore-based students and teachers through the project website, which is the location of a virtual "adoption center" for different notable microbes from the deep biosphere and for blogs announcing different weekly science and art activities and news from the expedition. Several shipboard scientists also contributed articles about their favorite microbe to the project website. The Adopt-A-Microbe project was also the portal for an art contest for decorating the subseafloor observatories installed during Expedition 336, representing the world's deepest art installation.

Thirty-five different school groups, after-school programs, and families from around the United States and Spain officially registered to participate in the 10 week project. Participants received a free kit of materials for using in the weekly projects-including samples of sand, clay, basalt, pyrite, calcite, and materials for growing microbes-which was supplied from the Deep Earth Academy. The participants varied in age, with high school marine science and biology classes making up a large proportion. Several participating teachers developed their own class projects using the Adopt-A-Microbe weekly activities as a base, and these are now available for sharing with other programs. For the first time, a Spanish-language section was also incorporated into the project website, translated by scientist Tania Lado Insua, to engage with elementary school students in Spain.

This online interactive project was hosted on the website for C-DEBI at aam.darkenergybiosphere.org/, with promotion through Facebook, Twitter, the JOIDES Resolution website and C-DEBI email listservs.

During Expedition 336, four special education classrooms in the Phoenix, Arizona, metro area interacted with shipboard scientists via weekly activities, blogs, question-and-answer sessions and Skype calls revolving around ocean exploration as part of the Classroom Connection initiative. The initiative was inspired by informal ship-to-classroom interactions during Expedition 327, during which one special education classroom in the Phoenix metro area read blogs and interviews written by shipboard scientists and submitted questions for the shipboard scientific party.

The Classroom Connection participants interacted with the shipboard scientific party via a web page hosted on the C-DEBI website (www.darkenergybiosphere.org/classroomconnection/) for a total of 10 weeks (9 weeks at sea plus 1 introductory week before the expedition). Each week followed a different theme (e.g., life on the JOIDES Resolution, coring/ drilling, logistics, data collection, etc.), and each day of the week involved a different type of interactionhands-on activities posted on Mondays, answers to student questions on Tuesdays, SciMath Career series interview on Wednesdays, blog on Thursdays, and WebDay Friday activities on Fridays-all revolving around the theme of the week. Each interaction addressed one or more Arizona state-mandated curriculum standards in one or more subjects (math, reading, writing, science, and social studies). The activities were designed to be easily adaptable to include every student in the classroom regardless of ability, and thus included several modes of assessment from reading and writing to pictorial representation, tactile models, and kinetic learning.

In addition to the classroom activities created for the Adopt-a-Microbe and Classroom Connection programs, three classroom activities were created for the 
JOIDES Resolution website. These activities focused on the process of deep-sea scientific drilling and combined art, math, creative thinking, technology, and the scientific process. The activities are ready to be tested in the classroom and will be added to the educational resources at Deep Earth Academy.

\section{References}

Arai, S., and Fujii, T., 1979. Petrology of ultramafic rocks from Site 395. In Melson, W.G., Rabinowitz, P.D., et al., Init. Repts. DSDP, 45: Washington, DC (U.S. Govt. Printing Office), 587-594. doi:10.2973/ dsdp.proc.45.134.1979

Bach, W., and Edwards, K.J., 2003. Iron and sulfide oxidation within the basaltic ocean crust: implications for chemolithoautotrophic microbial biomass production. Geochim. Cosmochim. Acta, 67(20):3871-3887. doi:10.1016/S0016-7037(03)00304-1

Bach, W., Humphris, S.E., and Fisher, A.T., 2004. Fluid flow and fluid-rock interaction within ocean crust: reconciling geochemical, geological, and geophysical observations. In Wilcock, W.S.D., Delong, E.F., Kelley, D.S., Baross, J.A., and Cary, C.S. (Eds.), The Subseafloor Biosphere at Mid-Ocean Ridges. Geophys. Monogr., 144:99118.

Bartetzko, A., Pezard, P., Goldberg, D., Sun, Y.-F., and Becker, K., 2001. Volcanic stratigraphy of DSDP/ODP Hole 395A: an interpretation using well-logging data. Mar. Geophys. Res., 22(2):111-127. doi:10.1023/ A:1010359128574

Becker, K., Langseth, M.G., and Hyndman, R.D., 1984. Temperature measurements in Hole 395A, Leg 78B. In Hyndman, R.D., Salisbury, M.H., et al., Init. Repts. DSDP, 78B: Washington, DC (U.S. Govt. Printing Office), 689698. doi:10.2973/dsdp.proc.78b.105.1984

Becker, K., Malone, M.J., et al., 1998. Proc. ODP, Init. Repts., 174B: College Station, TX (Ocean Drilling Program). doi:10.2973/odp.proc.ir.174B.1998

Becker, K., the Leg 174B Scientific Party, and Davis, E.E., 1998. Leg 174B revisits Hole 395A: logging and longterm monitoring of off-axis hydrothermal processes in young oceanic crust. JOIDES J., 24(1):1-3. http:// www.odplegacy.org/PDF/Admin/JOIDES_Journal/ JJ_1998_V24_No1.pdf

Cande, S.C., and Kent, D.V., 1995. Revised calibration of the geomagnetic polarity timescale for the Late Cretaceous and Cenozoic. J. Geophys. Res., [Solid Earth], 100(B4):6093-6095. doi:10.1029/94JB03098

Detrick, R., Honnorez, J., Bryan, W.B., Juteau, T., et al., 1988. Proc. ODP, Init. Repts., 106/109: College Station, TX (Ocean Drilling Program). doi:10.2973/ odp.proc.ir.106109.1988

Eberhard, C., Wirsen, C.O., and Jannasch, H.W., 1995. Oxidation of polymetal sulfides by chemolithoautotrophic bacteria from deep-sea hydrothermal vents. Geomicrobiol. J., 13(3):145-164. doi:10.1080/ 01490459509378014
Edwards, K.J., Bach, W., and Klaus, A., 2010. Mid-Atlantic Ridge flank microbiology: initiation of long-term coupled microbiological, geochemical, and hydrological experimentation within the seafloor at North Pond, western flank of the Mid-Atlantic Ridge. IODP Sci. Prosp., 336. doi:10.2204/iodp.sp.336.2010

Edwards, K.J., McCollom, T.M., Konishi, H., and Buseck, P.R., 2003a. Seafloor bioalteration of sulfide minerals: results from in situ incubation studies. Geochim. Cosmochim. Acta, 67(15):2843-2856. doi:10.1016/S00167037(03)00089-9

Edwards, K.J., Rogers, D.R., Wirsen, C.O., and McCollom, T.M., 2003b. Isolation and characterization of novel psychrophilic, neutrophilic, Fe-oxidizing, chemolithoauto-trophic alpha- and gamma-Proteobacteria from the Deep Sea. Appl. Environ. Microbiol. 69(5):2906-2913. doi:10.1128/AEM.69.5.2906-2913.2003

Edwards, K.J., Wheat, C.G., Orcutt, B.N., Hulme, S., Becker, K., Jannasch, H., Haddad, A., Pettigrew, T., Rhinehart, W., Grigar, K., Bach, W., Kirkwood, W., and Klaus, A., 2012. Design and deployment of borehole observatories and experiments during IODP Expedition 336, MidAtlantic Ridge flank at North Pond. In Edwards, K.J., Bach, W., Klaus, A., and the Expedition 336 Scientists, Proc. IODP, 336: Tokyo (Integrated Ocean Drilling Program Management International, Inc.). doi:10.2204/ iodp.proc.336.109.2012

Expedition 336 Scientists, 2012a. Site U1382. In Edwards, K.J., Bach, W., Klaus, A., and the Expedition 336 Scientists, Proc. IODP, 336: Tokyo (Integrated Ocean Drilling Program Management International, Inc.). doi:10.2204/iodp.proc.336.104.2012

Expedition 336 Scientists, 2012b. Site U1383. In Edwards, K.J., Bach, W., Klaus, A., and the Expedition 336 Scientists, Proc. IODP, 336: Tokyo (Integrated Ocean Drilling Program Management International, Inc.). doi:10.2204/iodp.proc.336.105.2012

Fisher, A.T., 2005. Marine hydrogeology: recent accomplishments and future opportunities. Hydrogeol. J., 13(1):69-97. doi:10.1007/s10040-004-0400-y

Fisher, A.T., and Becker, K., 2000. Channelized fluid flow in oceanic crust reconciles heat-flow and permeability data. Nature (London, U. K.), 403(6765):71-74. doi:10.1038/47463

Fisk, M.R., Giovannoni, S.J., and Thorseth, I.H., 1998. Alteration of oceanic volcanic glass: textural evidence of microbial activity. Science, 281(5379):978-980. doi:10.1126/science.281.5379.978

Furnes, H., Staudigel, H., Thorseth, I.H., Torsvik, T., Muehlenbachs, K., and Tumyr, O., 2001. Bioalteration of basaltic glass in the oceanic crust. Geochem., Geophys., Geosyst., 2(8):1049-1078. doi:10.1029/2000GC000150

Gable, R., Morin, R.H., and Becker, K., 1992. Geothermal state of DSDP Holes 333A, 395A and 534A: results from the DIANAUT program. Geophys. Res. Lett., 19(5):505508. doi:10.1029/92GL00333

Gieskes, J.M., and Magenheim, A.J., 1992. Borehole fluid chemistry of DSDP Holes 395A and 534A results from Operation Dianaut. Geophys. Res. Lett., 19(5):513-516. doi:10.1029/91GL02769 
Griffin, D.W., 2012. Long-range transatlantic transport of microorganisms in clouds of African desert dust: a study of atmospheric microbiology, chemistry, and the influence of desert dust on surface water microbial ecology aboard the R/V JOIDES Resolution, IODP Expedition 336, 16 September-16 November 2011. In Edwards, K.J., Bach, W., Klaus, A., and the Expedition 336 Scientists, Proc. IODP, 336: Tokyo (Integrated Ocean Drilling Program Management International, Inc.). doi:10.2204/ iodp.proc.336.110.2012

Hickman, S.H., Langseth, M.G., and Svitek, J.F., 1984. In situ permeability and pore-pressure measurements near the Mid-Atlantic Ridge, Deep Sea Drilling Project Hole 395A. In Hyndman, R.D., Salisbury, M.H., et al., Init. Repts. DSDP, 78B: Washington, DC (U.S. Govt. Printing Office), 699-708. doi:10.2973/

dsdp.proc.78b.106.1984

Hyndman, R.D., Salisbury, M.H., et al., 1984. Init. Repts. DSDP, 78B: Washington, DC (U.S. Govt. Printing Office). doi:10.2973/dsdp.proc.78b.1984

Knab, N., and Edwards, K.J., in press. Competition between kinetics of chemical and biological iron oxidation: environmental implications. Geobiology.

Langseth, M.G., Becker, K., Von Herzen, R.P., and Schultheiss, P., 1992. Heat and fluid flux through the sediment on the western flank of the Mid-Atlantic Ridge: a hydrogeological study of North Pond. Geophys. Res. Lett., 19(5):517-520. doi:10.1029/92GL00079

Langseth, M.G., Hyndman, R., Becker, K., Hickman, S.H., and Salisbury, M., 1984. The hydrogeological regime of isolated sediment ponds in mid-oceanic ridges. In Hyndman, R.D., Salisbury, M.H., et al., Init. Repts. DSDP, 78B: Washington, DC (U.S. Govt. Printing Office), 825837. doi:10.2973/dsdp.proc.78b.117.1984

Matthews, M., Salisbury, M.H., and Hyndman, R., 1984. Basement logging on the Mid-Atlantic Ridge, Deep Sea Drilling Project Hole 395A. In Hyndman, R.D., Salisbury, M.H., et al., Init. Repts. DSDP, 78B: Washington, DC (U.S. Govt. Printing Office, 717-730. doi:10.2973/ dsdp.proc.78b.108.1984

McDuff, R.E., 1984. The chemistry of interstitial waters from the upper ocean crust, Site 395, Deep Sea Drilling Project Leg 78B. In Hyndman, R.D., Salisbury, M.H., et al., Init. Repts. DSDP, 78B: Washington, DC (U.S. Govt. Printing Office), 795-799. doi:10.2973/ dsdp.proc.78b.114.1984

Melson, W.G., Rabinowitz, P.D., et al., 1979. Init. Repts. DSDP, 45: Washington, DC (U.S. Govt. Printing Office). doi:10.2973/dsdp.proc.45.1979

Orcutt, B., Wheat, C.G., and Edwards, K.J., 2010. Subseafloor ocean crust microbial observatories: development of FLOCS (Flow-Through Osmo Colonization System) and evaluation of borehole construction materials. Geomicrobiol. J., 27(2):143-157. doi:10.1080/ 01490450903456772
Orcutt, B.N., Bach, W., Becker, K., Fisher, A.T., Hentscher, M., Toner, B.M., Wheat, C.G., and Edwards, K.J., 2011 a. Colonization of subsurface microbial observatories deployed in young ocean crust. ISME J., 5(4):692-703. doi:10.1038/ismej.2010.157

Orcutt, B.N., Bowman, D., Inderbitzen, K., Haddad, A., Fisher, A.T., and Peart, L., 2011b. The 'Adopt-A-Microbe' project: web-based interactive microbiology education connected with scientific ocean drilling. Curr.: J. Mar. Educ., 27(3):40-44.

Rogers, D.R., Santelli, C.M., and Edwards, K.J., 2003. Geomicrobiology of deep-sea deposits: estimating community diversity from low-temperature seafloor rocks and minerals. Geobiology, 1(2):109-117. doi:10.1046/j.14724669.2003.00009.x

Schmidt-Schierhorn, F., Kaul, N., Stephan, S., and Villinger, H., 2012. Geophysical site survey results from North Pond (Mid-Atlantic Ridge). In Edwards, K.J., Bach, W., Klaus, A., and the Expedition 336 Scientists, Proc. IODP, 336: Tokyo (Integrated Ocean Drilling Program Management International, Inc.). doi:10.2204/ iodp.proc.336.107.2012

Shipboard Scientific Party, 1979. Site 395: $23^{\circ} \mathrm{N}$, MidAtlantic Ridge. In Melson, W.G., Rabinowitz, P.D., et al., Init. Repts. DSDP, 45: Washington, DC (U.S. Govt. Printing Office), 131-264. doi:10.2973/ dsdp.proc.45.107.1979

Sinton, J.M., 1979. Petrology of (alpine-type) peridotites from Site 395, DSDP Leg 45. In Melson, W.G., Rabinowitz, P.D., et al., Init. Repts. DSDP, 45: Washington, DC (U.S. Govt. Printing Office), 595-601. doi:10.2973/ dsdp.proc.45.135.1979

Villinger, H., and Cruise Participants, 2010. Short cruise report: RV Maria S. Merian Cruise MSM11/1. http:// www.ifm.zmaw.de/fileadmin/files/leitstelle/merian/ MSM11/MSM11-1-SCR.pdf

Wheat, C.G., Jannasch, H.W., Kastner, M., Plant, J.N., and DeCarlo, E.H., 2003. Seawater transport and reaction in upper oceanic basaltic basement: chemical data from continuous monitoring of sealed boreholes in a ridge flank environment. Earth Planet. Sci. Lett., 216(4):549564. doi:10.1016/S0012-821X(03)00549-1

Wirsen, C.O., Brinkhoff, T., Kuever, J., Muyzer, G., Molyneaux, S., and Jannasch, H.W., 1998. Comparison of a new Thiomicrospira strain from the Mid-Atlantic Ridge with known hydrothermal vent isolates. Appl. Environ. Microbiol., 64(10):4057-4059. http://aem.asm.org/cgi/ content/full/64/10/4057

Wirsen, C.O., Jannasch, H.W., and Molyneaux, S.J., 1993. Chemosynthetic microbial activity at Mid-Atlantic Ridge hydrothermal vent sites. J. Geophys. Res., [Solid Earth], 98(B6):9693-9703. doi:10.1029/92JB01556

Publication: 16 November 2012 MS 336-101 
Figure F1. Location map of North Pond area on the western flank of the Mid-Atlantic Ridge.

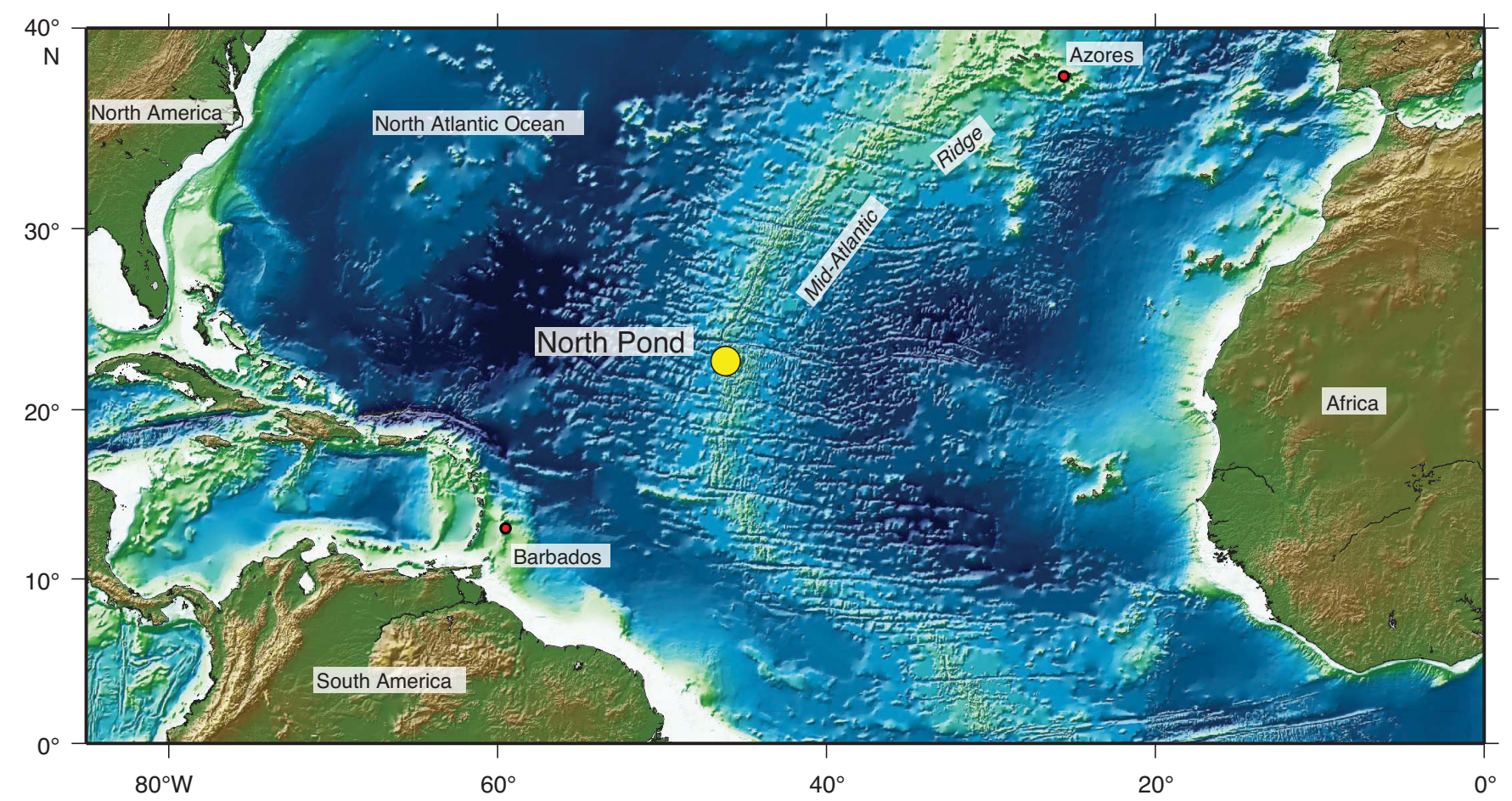


Figure F2. Bathymetric map of North Pond showing locations of DSDP Hole 395A, ODP Hole 1074A, and Sites U1382, U1383 (proposed Site NP-2), and U1384 (Proposed Site NP-1). Bathymetric data are from Villinger and Cruise Participants (2010).

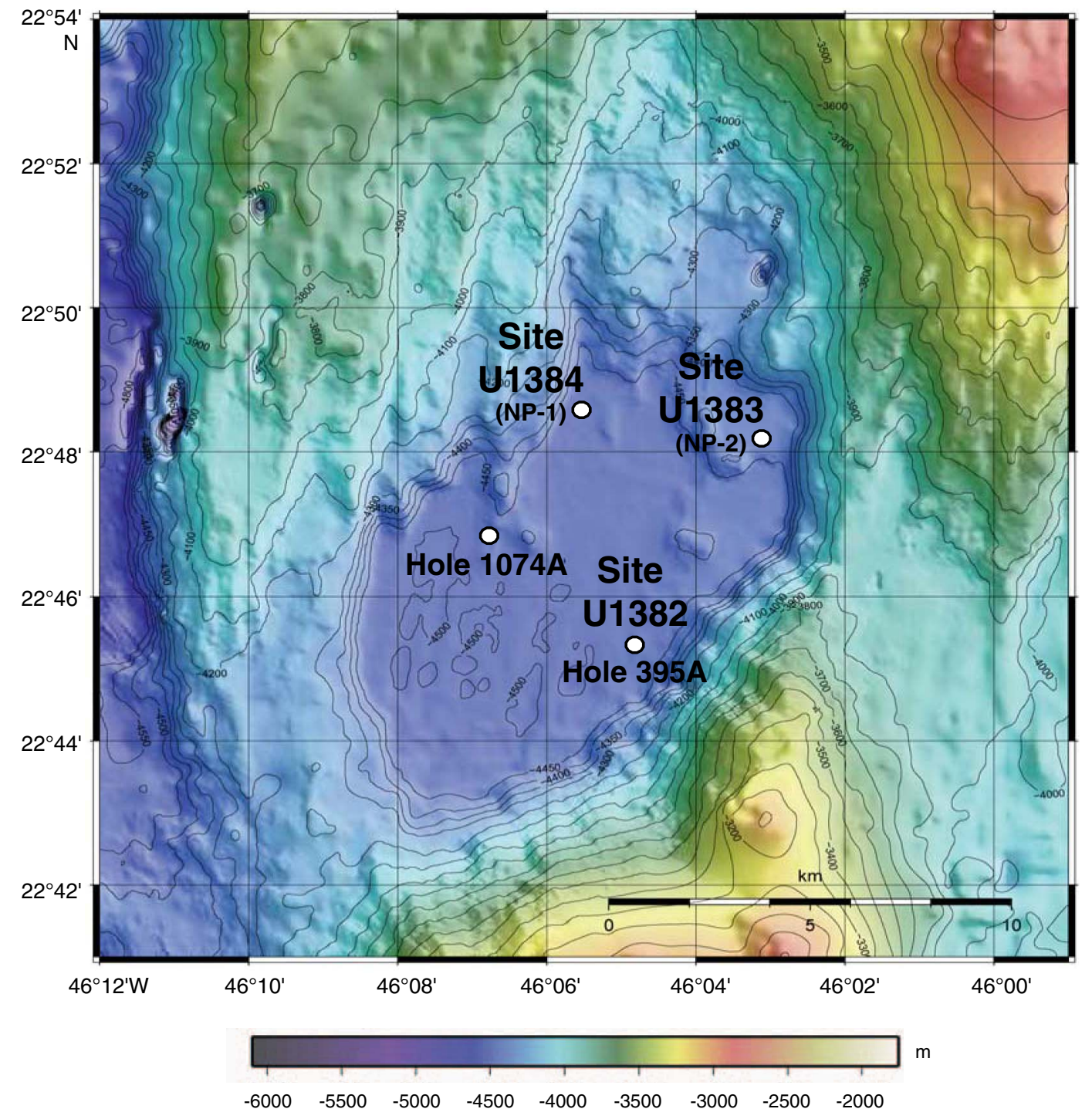


Figure F3. Summary of Hole 395A logging results. Blue lines = eruptive unit divisions (after Bartetzko et al., 2001), black lines = limits of casing and pipe for Expedition 336 operations. Arrows mark trends in gamma ray and resistivity. Measurements include borehole diameter $(\mathrm{C} 1, \mathrm{C} 2=\mathrm{FMS}$ pass [ODP Leg 174B]), gamma ray (TGR 174B ARI = total gamma ray [TGR] counts from Azimuthal Resistivity Imager tool string [Leg 174B]; TGR 174B DIT = TGR counts from Dual Induction Sonde tool string [Leg 174B]; TGR 395A 2U2 = TGR counts from Microbiology Combination tool string Run 2, Uplog 2 [Expedition 336]; TGR 395A 2D1 = TGR counts from the Microbiology Combination tool string Run 2, Downlog 1 [Expedition 336]), bulk density (Leg 174B), resistivity (174B IMPH = medium induction phasor-processed resistivity, 174B IDPH = deep induction phasorprocessed resistivity [both Leg $174 \mathrm{~B}])$, and $P$-wave velocity $\left(174 \mathrm{~B} V_{\mathrm{P}}=\right.$ compressional wave velocity measured with downhole sonic sonde [Leg

. Drilling Project. Electrofacies log after Bartetzko et al. (2001).

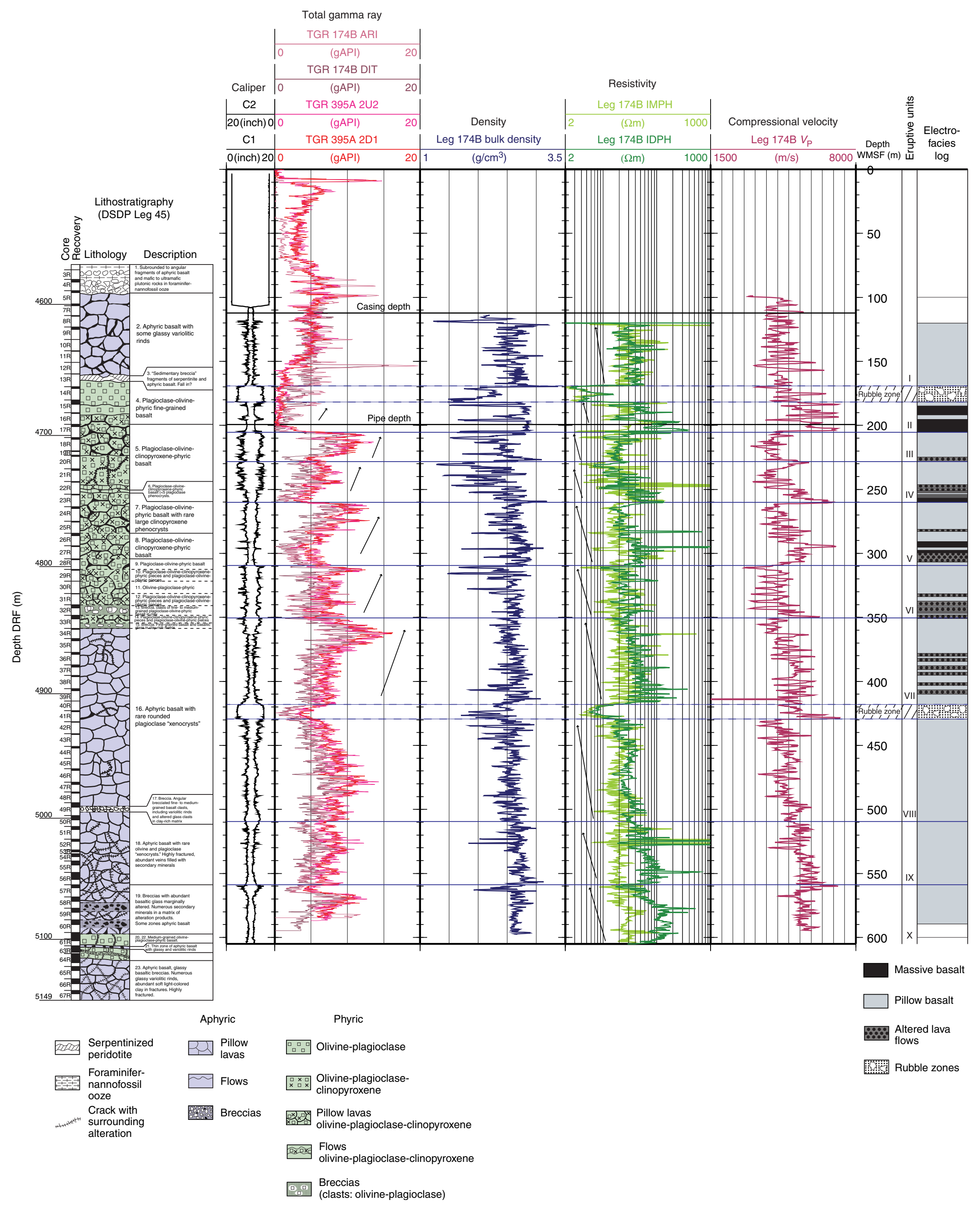


Figure F4. Configuration of the primary parts of the new subseafloor borehole observatory (CORK) deployed in Hole 395A. Red " $\mathrm{X}$ " marks the portion of the CORK head that broke off during the final step of installation (see text for explanation).

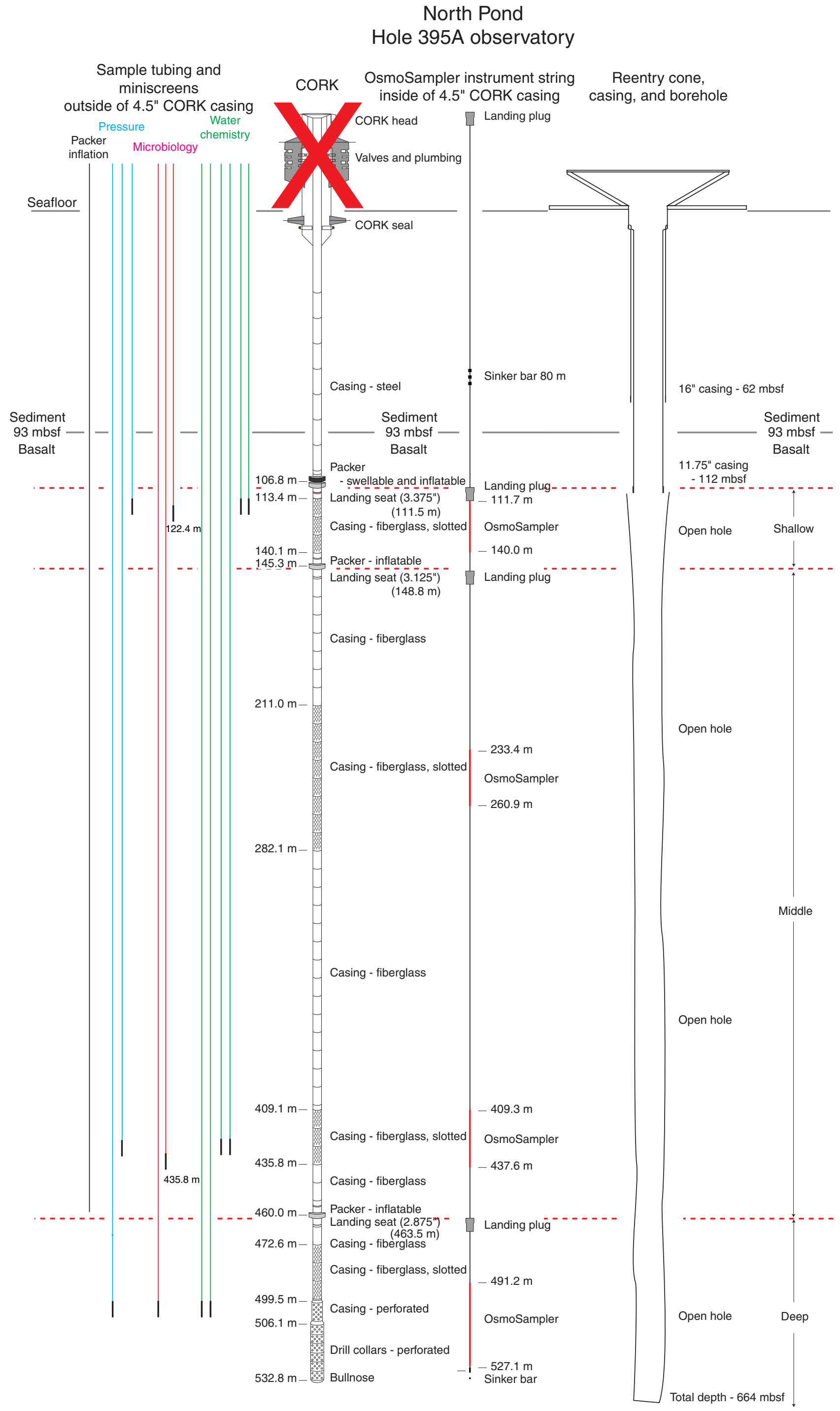


Figure F5. Summary of Hole U1382A logging results. Blue lines $=\log$ unit divisions, black lines $=$ limits of pipe and casing. Measurements include borehole diameter (CALI = adapted microbiology combination I [AMC I] uplog; C1, C2 = Formation MicroScanner [FMS] Pass 1), gamma ray (TGR FMS p2, TGR FMS p1 = total gamma ray [TGR] from FMS-HNGS Pass 1, Pass 2; TGR FMS DL = TGR from FMS-HNGS downlog; TGR EDTC DL = TGR from AMC I downlog), density ( $\mathrm{MAD}=$ moisture and density testing on discrete samples, bulk density $\mathrm{HR}=$ high-resolution data from AMC I uplog, bulk density = from AMC I uplog), resistivity (RLA5 UL, RLA5 DL = deepest resistivity from AMC I uplog, downlog; RLA4 UL and RLA4 DL = deep resistivity from AMC I uplog, downlog), and temperature (Temp UL, Temp DL = temperature from logging equipment head-mud temperature sensor on AMC I uplog, downlog). A summary of core recovery and lithologic units is provided at the far left.

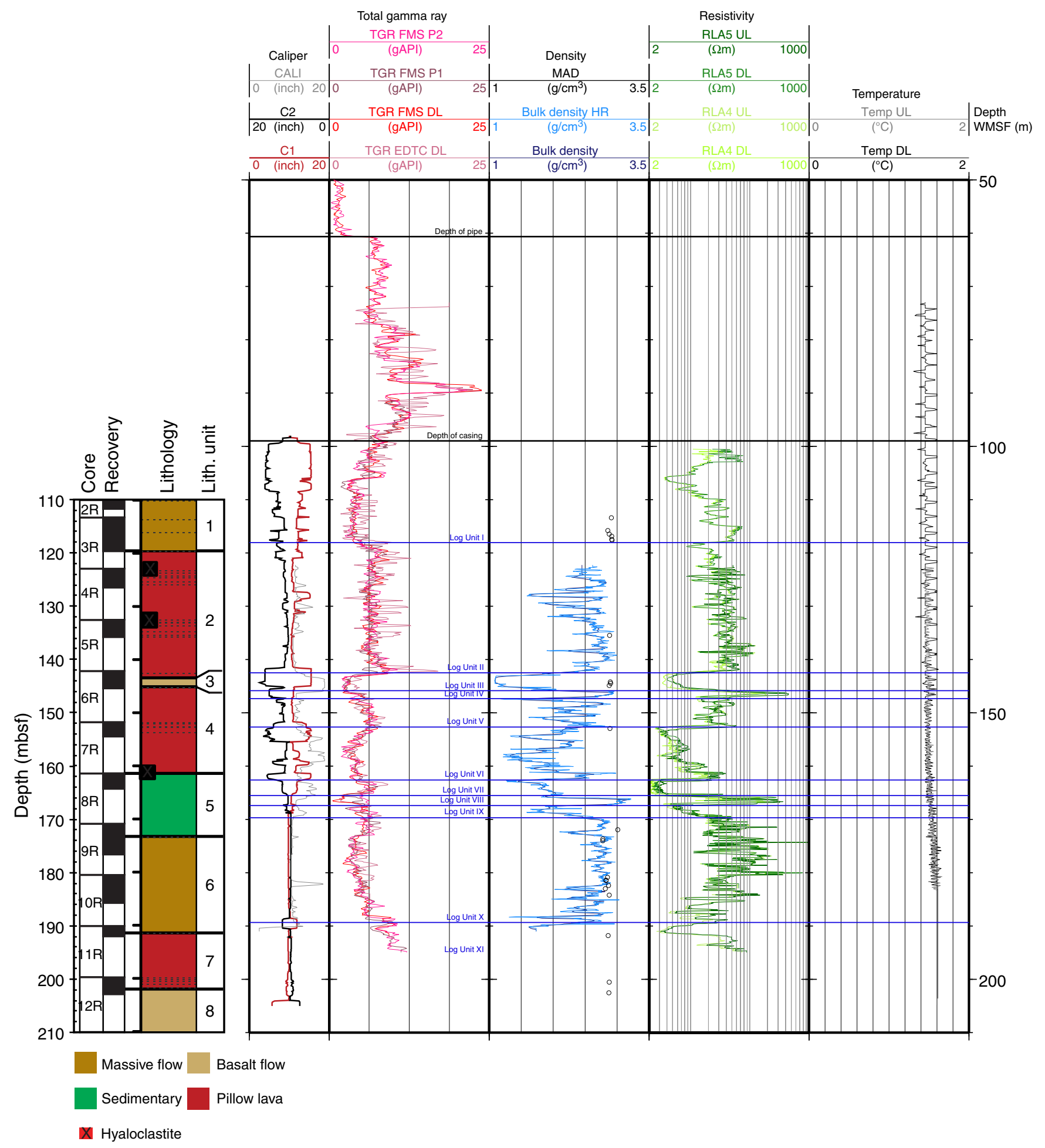


Figure F6. Configuration of the primary parts of the subseafloor borehole observatory (CORK) installed in Hole U1382A.

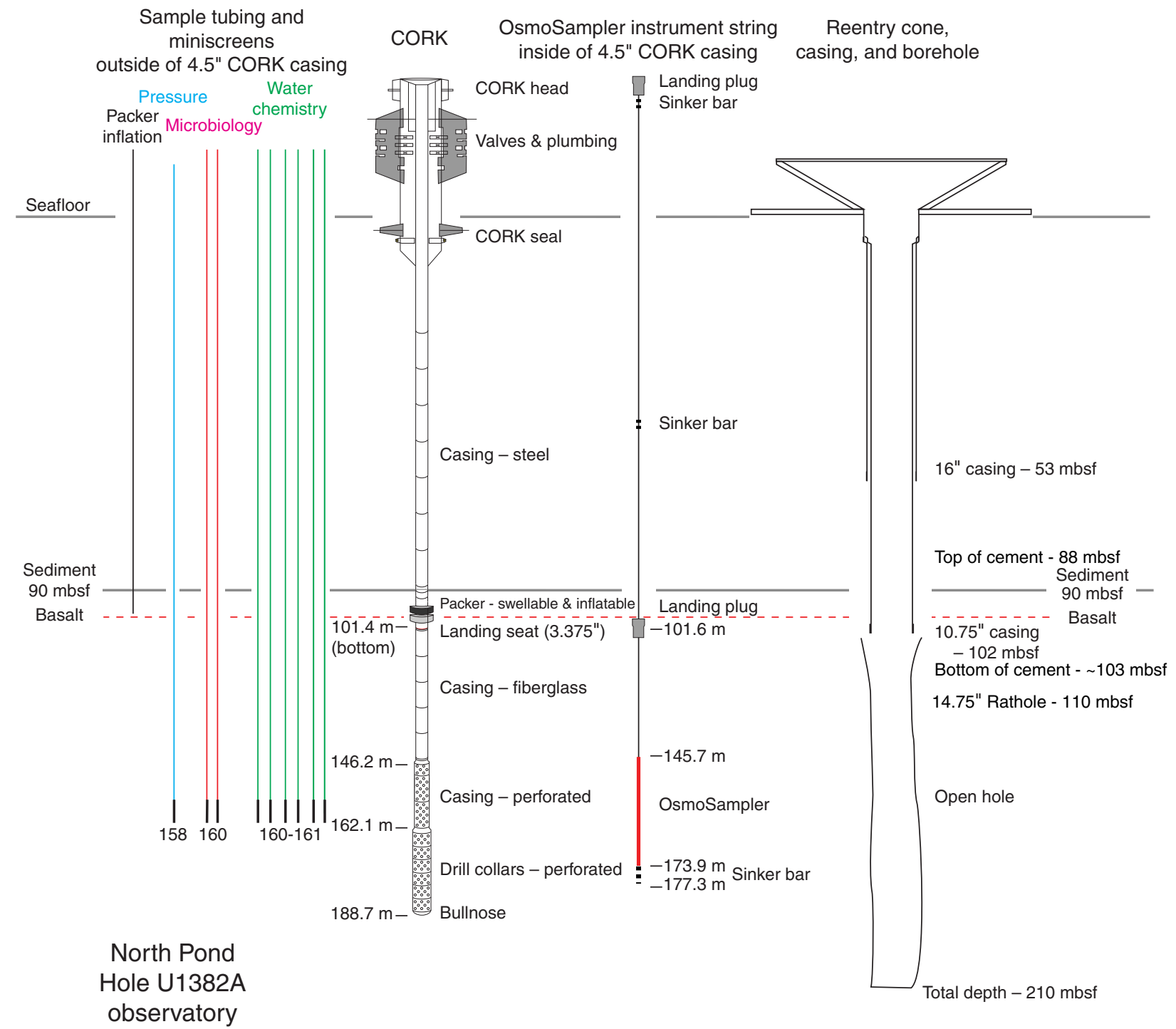


Figure F7. Schematic of the reentry cone and casing installed in Hole U1383B. CSG = casing, TD = total depth.

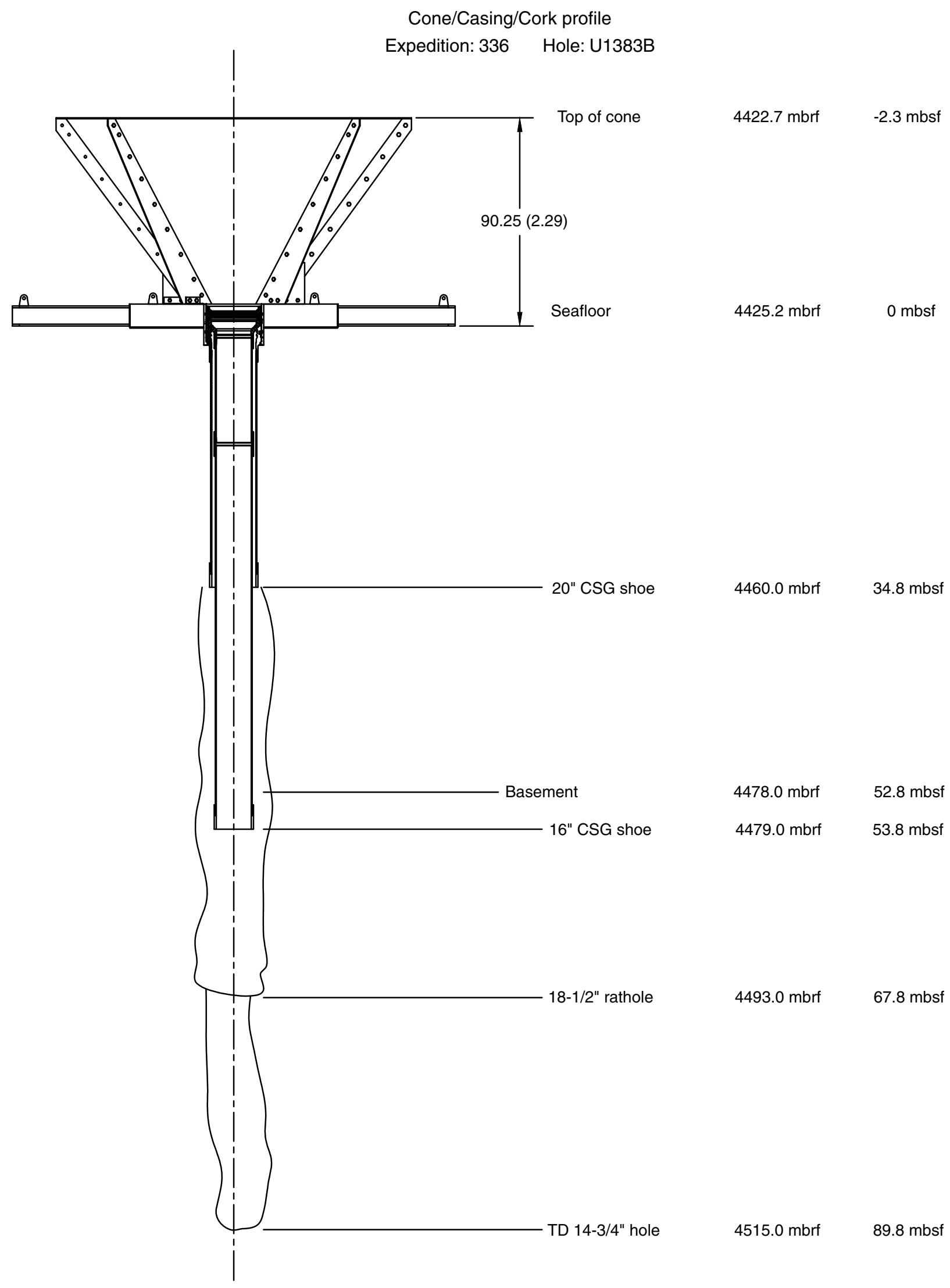


Figure F8. Summary of Hole U1383C logging results. Blue lines $=\log$ unit divisions, black lines = limits of pipe and casing. Measurements include borehole diameter (CALI = adapted microbiology combination II [AMC II] Uplog 1; FMS C1, C2 = Formation MicroScanner [FMS] Pass 1), gamma ray (TGR AMCII UL2 = total gamma ray [TGR] from AMC II Uplog 2; TGR FMS P1, P2 = TGR from FMS-sonic Pass 1, Pass 2; TGR AMCII D1 = TGR from AMC II Downlog 1), density (bulk density = from AMC II Uplogs 1 and 2; MAD = moisture and density testing on discrete core samples), apparent resistivity (calculated resistivity FMS P2, FMS P1 = calculated resistivity from FMS pad average from Pass 1 , Pass 2$)$, compressional velocity $\left(V_{\mathrm{P}}\right.$ core $=$ from discrete core cube samples; $V_{\mathrm{P}} \mathrm{P} 1$, P2 = from FMS-sonic Pass 1, Pass 2). A summary of core recovery and lithologic units is provided at the far left, and on the far right is electrical stratigraphy based on FMS electrical images.

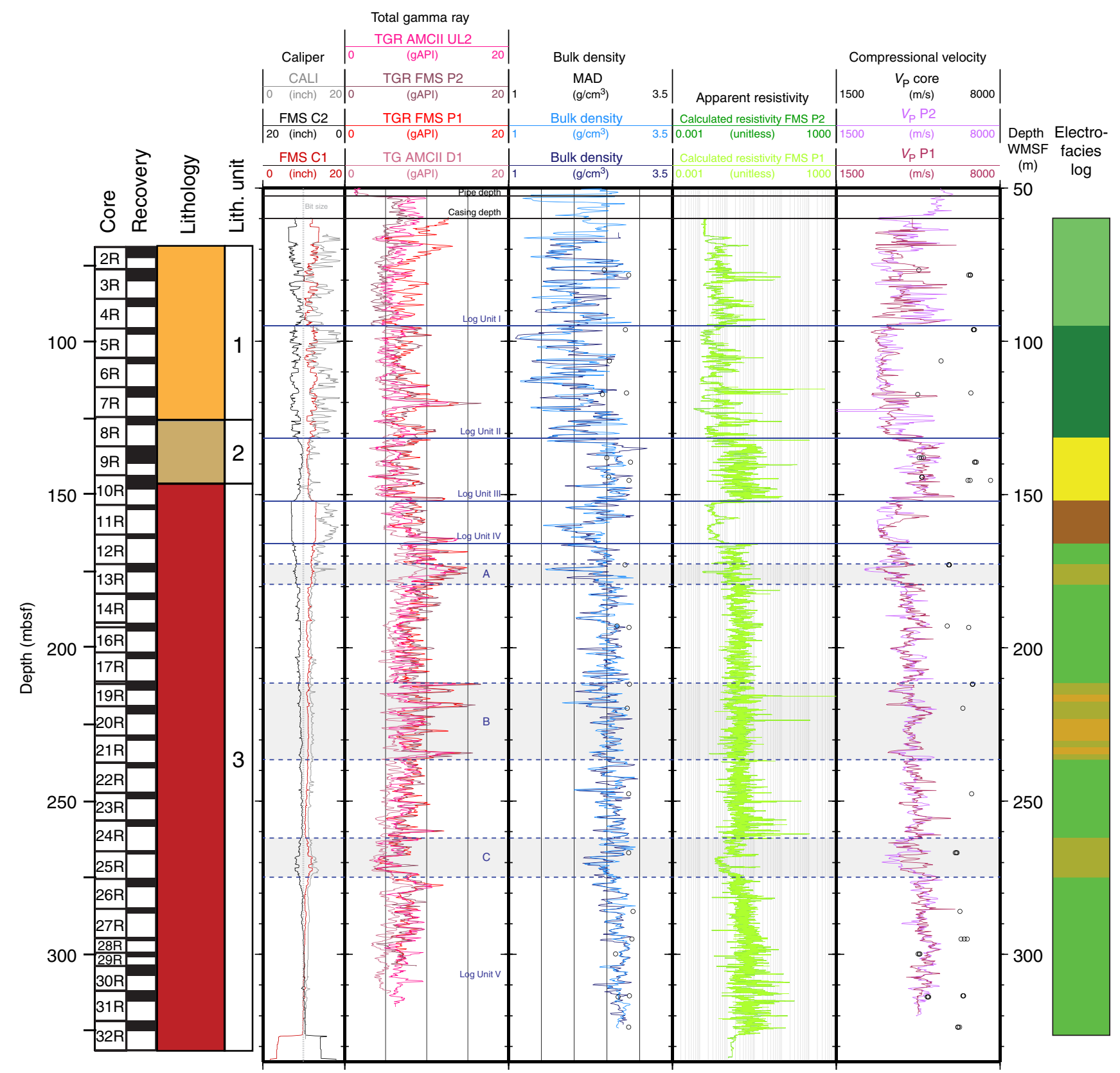

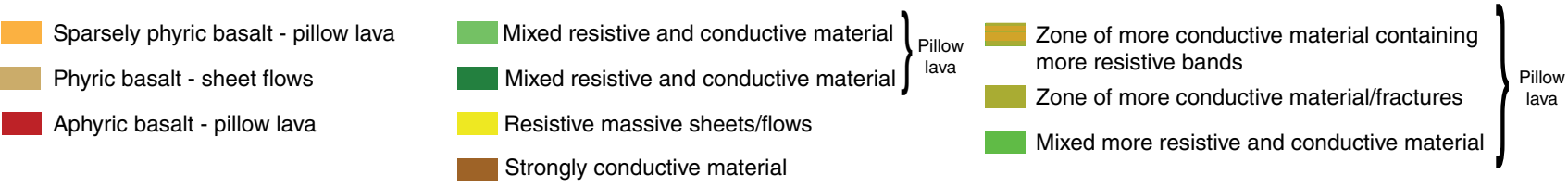


Figure F9. Configuration of the primary parts of the subseafloor borehole observatory (CORK) installed in Hole U1383C.

North Pond
Hole U1383C
observatory

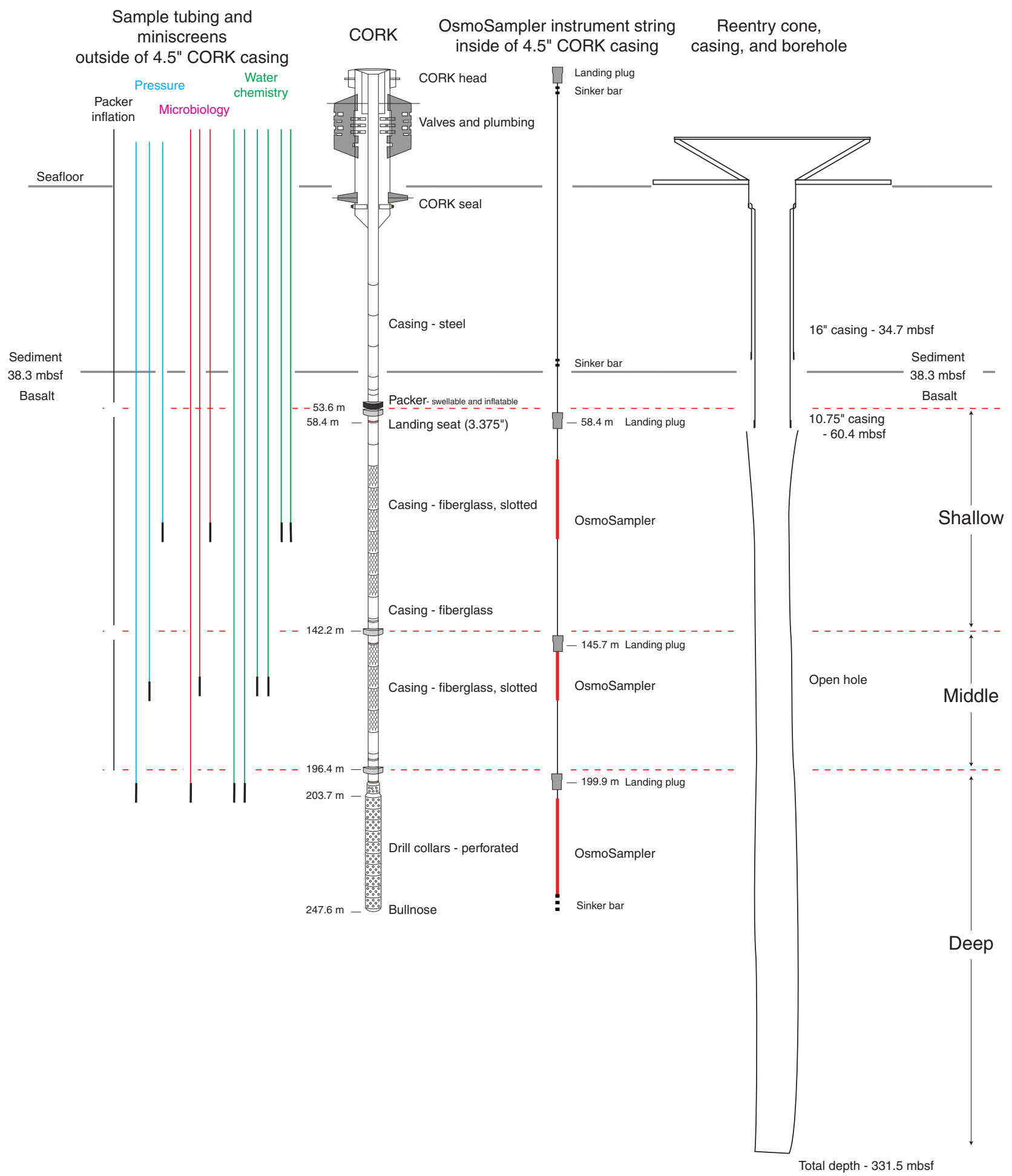


Figure F10. Summary of basement section cored, Hole U1383C. TGR = total gamma ray, AMCII = adapted microbiology combination II.

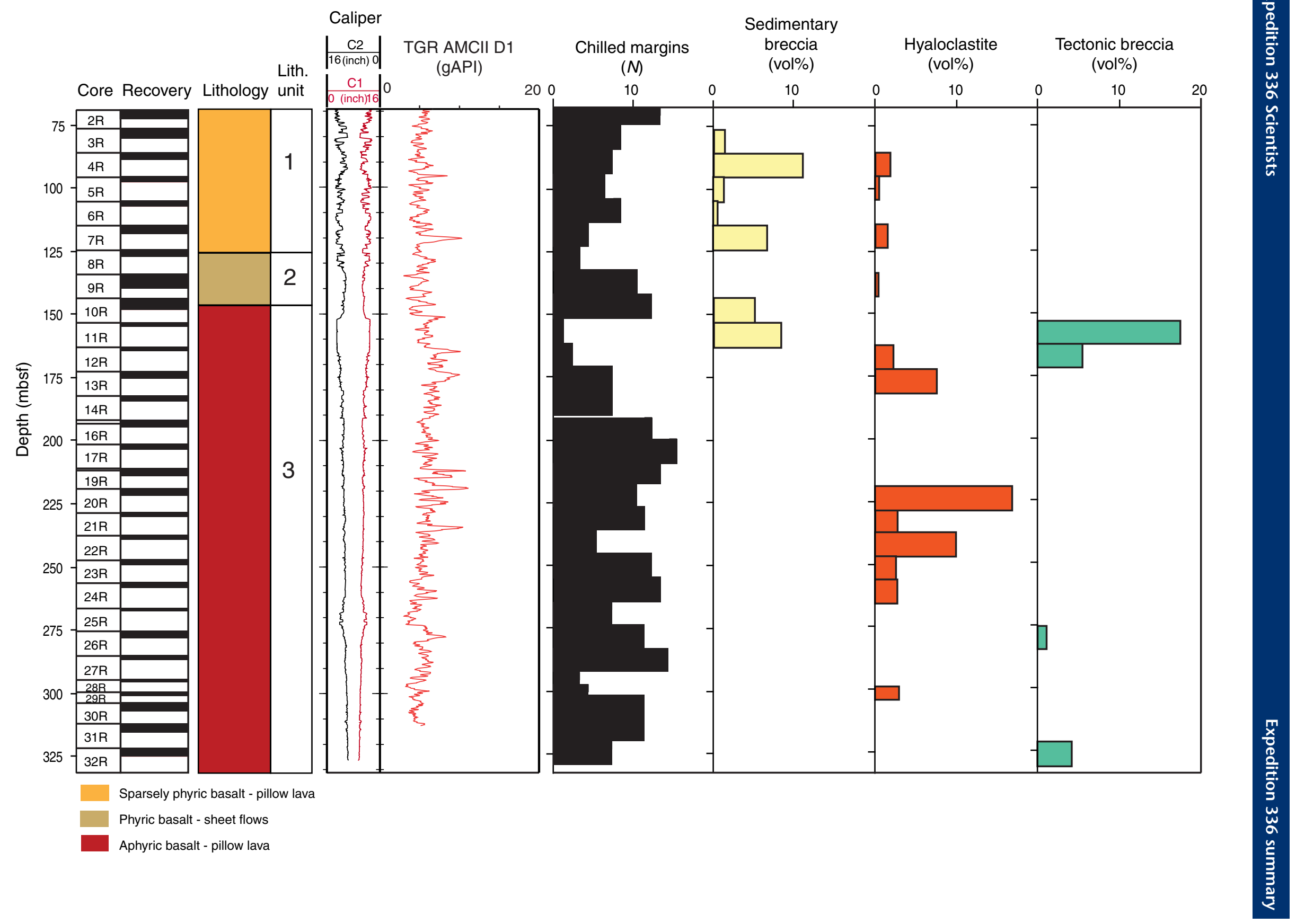


Figure F11. Summary of alteration and basement section cored, Hole U1383C.

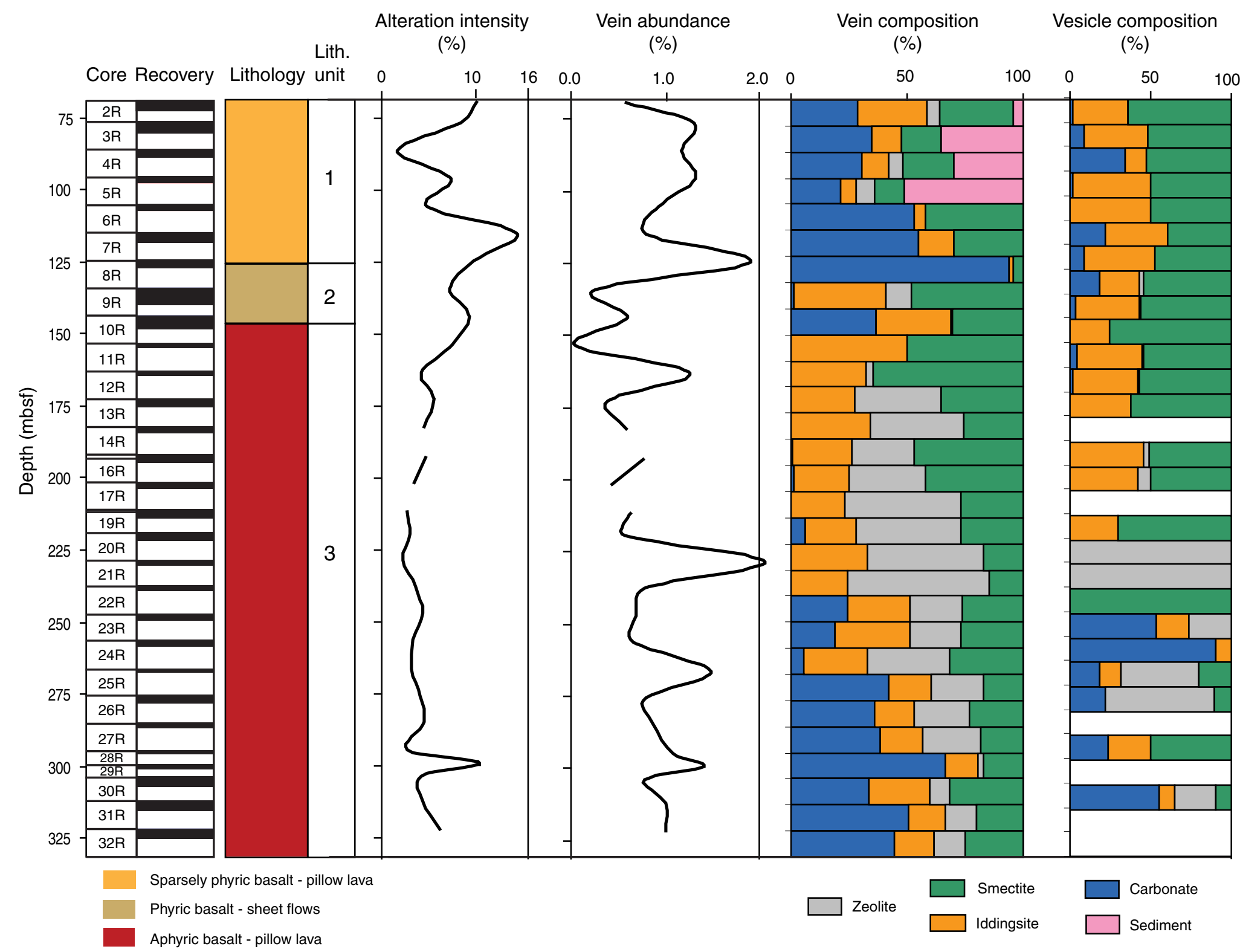


Figure F12. Summary of basement section cored, Hole U1382A. TGR FMS dl = total gamma ray from Formation MicroScanner-HNGS downlog.
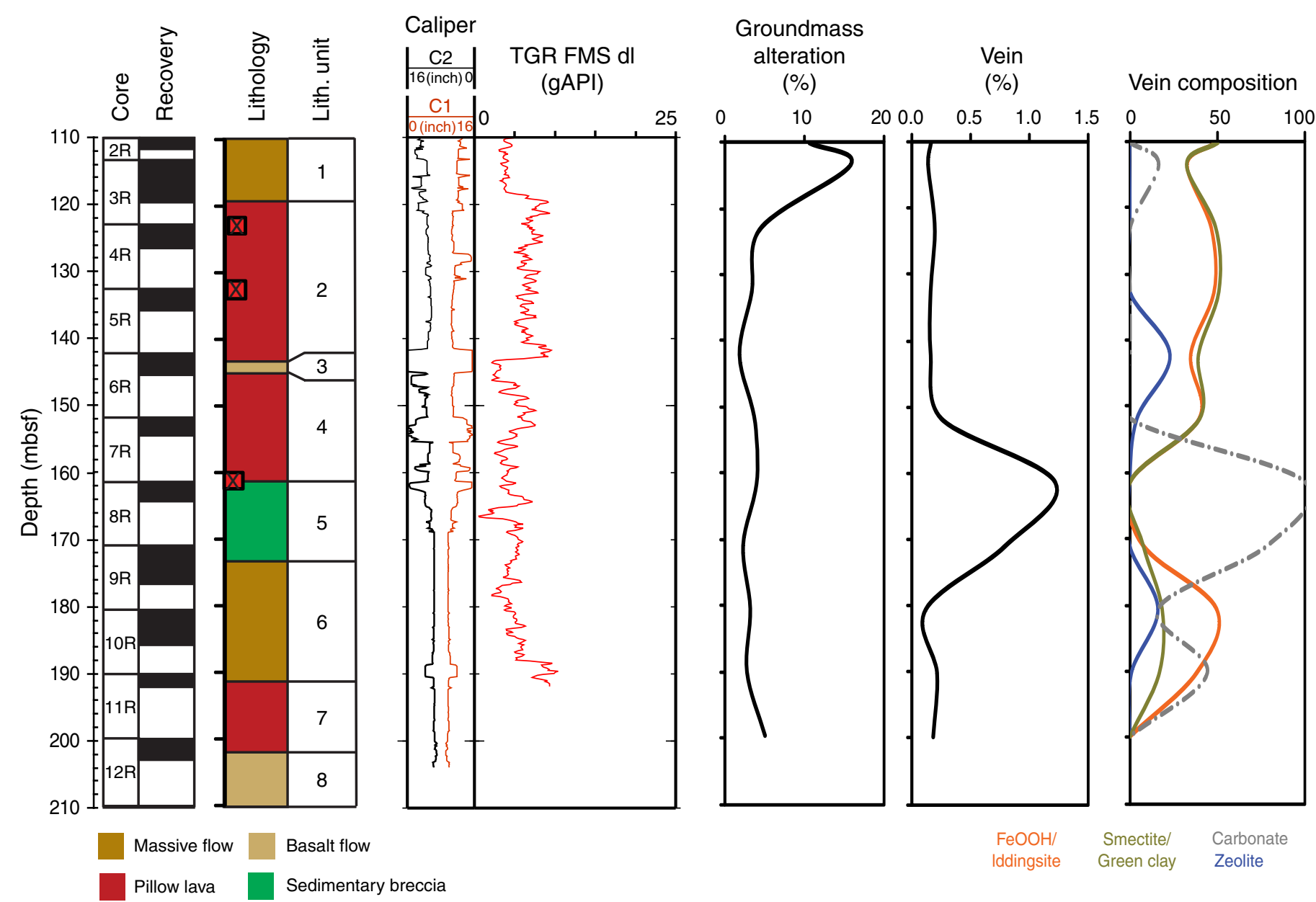
Figure F13. Comparison of page views (top) and visits (bottom) to the JOIDES Resolution website (joidesresolution.org/) during three different time periods.

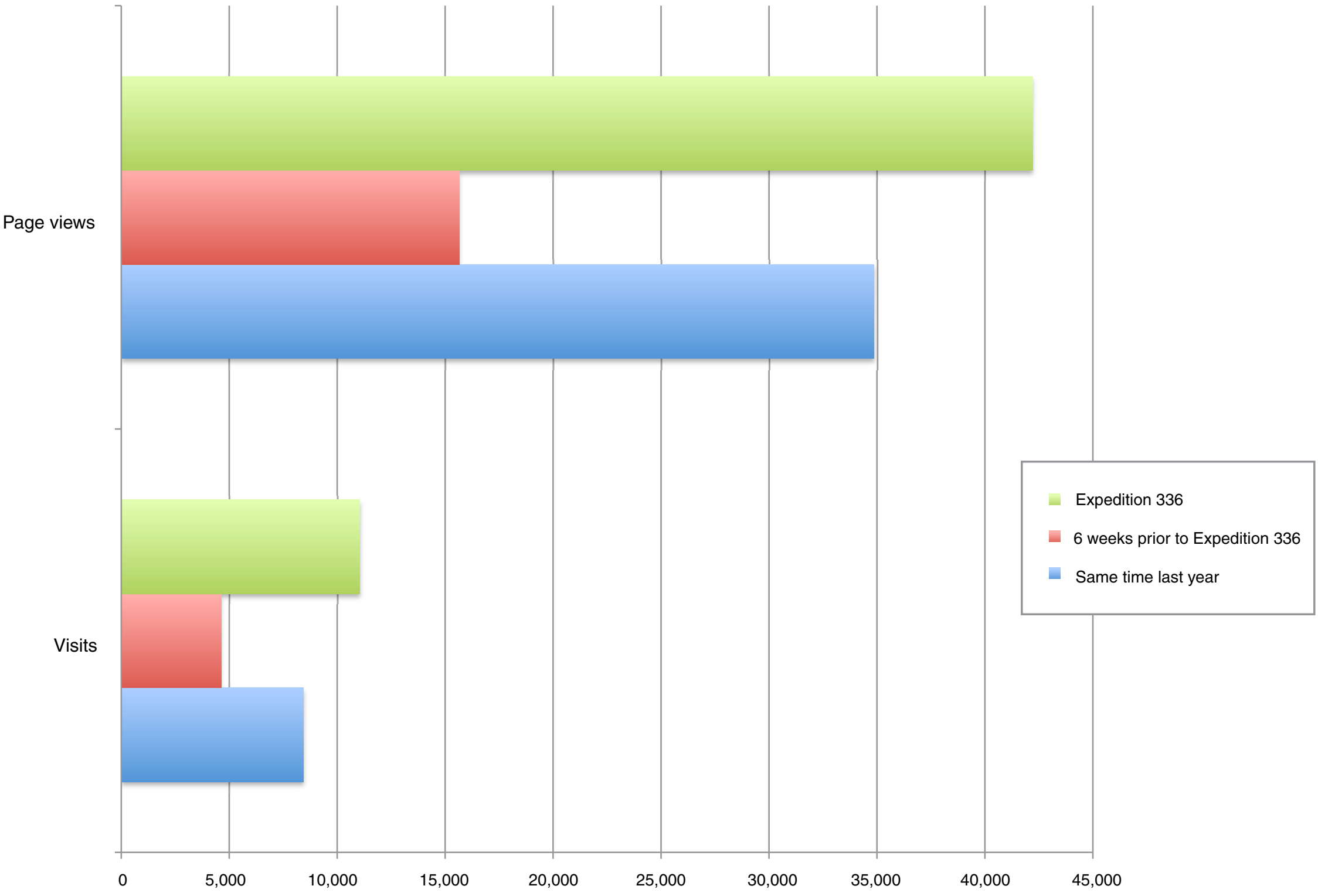


Table T1. Summary of educational videoconferences during Expedition 336.

\begin{tabular}{|c|c|c|c|c|c|c|}
\hline $\begin{array}{l}\text { Date } \\
(2011)\end{array}$ & Grade level/Class & $\begin{array}{l}\text { Number of } \\
\text { students }\end{array}$ & Venue & City & State & Country \\
\hline 23 Sept & $11-12$ th grade & 6 & Erindale College & Canberra & ACT & Australia \\
\hline 26 Sept & $11-12$ th grade elective & 24 & St. Joseph's Academy & St. Louis & MO & USA \\
\hline 28 Sept & 5 th grade gifted students & 10 & Maclary Elementary & Oxford & PA & USA \\
\hline 30 Sept & 11-12th grade Astronomy & 40 & North Hollywood Zoo Magnet & Los Angeles & $\mathrm{CA}$ & USA \\
\hline $3 \mathrm{Oct}$ & 8 th grade & 32 & St. Anne School & Lancaster & PA & USA \\
\hline 4 Oct & 11-12th grade elective & 24 & St. Joseph's Academy & St. Louis & $\mathrm{MO}$ & USA \\
\hline 5 Oct & 12th grade Marine Biology & 40 & Animo Leadership High School & Inglewood & $\mathrm{CA}$ & USA \\
\hline $5 \mathrm{Oct}$ & 9-12th grade Marine Biology Club & 40 & Animo Leadership High School & Inglewood & $\mathrm{CA}$ & USA \\
\hline $6 \mathrm{Oct}$ & $11-12$ th grade & 40 & River Ridge High School & New Pt. Richey & $\mathrm{FL}$ & USA \\
\hline 7 Oct & 6 th grade & 60 & Marina del Rey Middle School & Los Angeles & $\mathrm{CA}$ & USA \\
\hline $10 \mathrm{Oct}$ & Naval and Ocean Engineering & 20 & University of La Coruña & A Coruña & & Spain \\
\hline 11 Oct & 5 th grade & 40 & Polo Road Elementary School & Columbia & SC & USA \\
\hline 11 Oct & 5 th grade & 40 & Polo Road Elementary School & Columbia & SC & USA \\
\hline $12 \mathrm{Oct}$ & 6 th grade & 32 & South Gate Middle School & South Gate & $\mathrm{CA}$ & USA \\
\hline 13 Oct & University & 50 & Institut Universitaire Européen de la Mer & Plouzané & & France \\
\hline 14 Oct & 10th grade Biology & 24 & St. Joseph's Academy & St. Louis & $\mathrm{MO}$ & USA \\
\hline 14 Oct & University & 40 & University of the Virgin Islands & St. Thomas & VI & $\mathrm{VI}$ \\
\hline 18 Oct & Form 8 & 20 & St Philip's School & London & & United Kingdom \\
\hline 18 Oct & University & 300 & Colorado State University & Niwot & $\mathrm{CO}$ & USA \\
\hline 19 Oct & 8 th grade & 30 & Quibbletown Middle School & Piscataway & NJ & USA \\
\hline 19 Oct & 8 th grade & 30 & Quibbletown Middle School & Piscataway & NJ & USA \\
\hline 20 Oct & 8 th grade & 30 & Quibbletown Middle School & Piscataway & NJ & USA \\
\hline $20 \mathrm{Oct}$ & $6-8$ th grade & 50 & The International School of Monterey & Seaside & $\mathrm{CA}$ & USA \\
\hline 21 Oct & 8 th grade & 30 & Quibbletown Middle School & Piscataway & NJ & USA \\
\hline 21 Oct & HS special needs & 20 & Challenger Middle School & Glendale & $A Z$ & USA \\
\hline 24 Oct & $7-8$ th grade & 40 & Nobel Middle School-Marine Science & Calabasas & $\mathrm{CA}$ & USA \\
\hline $25 \mathrm{Oct}$ & $6-8$ th grade & 60 & $\begin{array}{l}\text { Providence Englewood Charter School } \\
\text { Middle School }\end{array}$ & Chicago & $\mathrm{IL}$ & USA \\
\hline 26 Oct & $8-9$ year olds & 20 & La escuela Manuela Rial en Cee & A Coruña & & Spain \\
\hline 26 Oct & $11-12$ th grade & 5 & AIM (Academy in Manayunk) & Philadelphia & PA & USA \\
\hline 27 Oct & $7-8$ th grade & 40 & Nobel Middle School-Marine Science & Calabasas & $\mathrm{CA}$ & USA \\
\hline 28 Oct & University & 50 & Texas A\&M University & College Station & TX & USA \\
\hline 31 Oct & 9th grade Earth/Environmental Science & 30 & Croatan High School & Newport & NC & USA \\
\hline $1 \mathrm{Nov}$ & 4-12th grade club & 14 & CyberExplorers 4H Club & Cape May & $\mathrm{NJ}$ & USA \\
\hline $1 \mathrm{Nov}$ & 5 th grade & 30 & Arroyo Vista Elementary School & South Pasadena & $\mathrm{CA}$ & USA \\
\hline $2 \mathrm{Nov}$ & 7th grade Life Science & 30 & Trinity Lutheran School & Newport News & VA & USA \\
\hline $3 \mathrm{Nov}$ & 6 th grade Life Science +7 th grade Earth Science & 44 & Allen Academy & Bryan & TX & USA \\
\hline $3 \mathrm{Nov}$ & 5 th grade & 30 & Arroyo Vista Elementary School & South Pasadena & $\mathrm{CA}$ & USA \\
\hline $4 \mathrm{Nov}$ & 7 th grade & 25 & Pound Middle School & Lincoln & NE & USA \\
\hline $4 \mathrm{Nov}$ & 7 th grade & 25 & Pound Middle School & Lincoln & NE & USA \\
\hline $4 \mathrm{Nov}$ & 9th grade Biology & 15 & Allen Academy & Bryan & TX & USA \\
\hline $8 \mathrm{Nov}$ & 3 rd grade & 25 & Arroyo Vista Elementary School & South Pasadena & $\mathrm{CA}$ & USA \\
\hline $9 \mathrm{Nov}$ & 6th grade & 60 & Mayport Coastal Sciences Middle School & Atlantic Beach & $\mathrm{FL}$ & USA \\
\hline $10 \mathrm{Nov}$ & $6-8$ th grade & 60 & $\begin{array}{l}\text { Providence Englewood Charter School } \\
\text { Middle School }\end{array}$ & Chicago & IL & USA \\
\hline $11 \mathrm{Nov}$ & University & 30 & University of Leicester & Leicester & & United Kingdom \\
\hline $11 \mathrm{Nov}$ & 9th grade & 38 & Eastern Mennonite High School & Harrisonburg & VA & USA \\
\hline $11 \mathrm{Nov}$ & 9th grade & 38 & Eastern Mennonite High School & Harrisonburg & VA & USA \\
\hline $15 \mathrm{Nov}$ & Adults & 40 & Association of Earth Science Editors & Tallahassee & $\mathrm{FL}$ & USA \\
\hline
\end{tabular}

